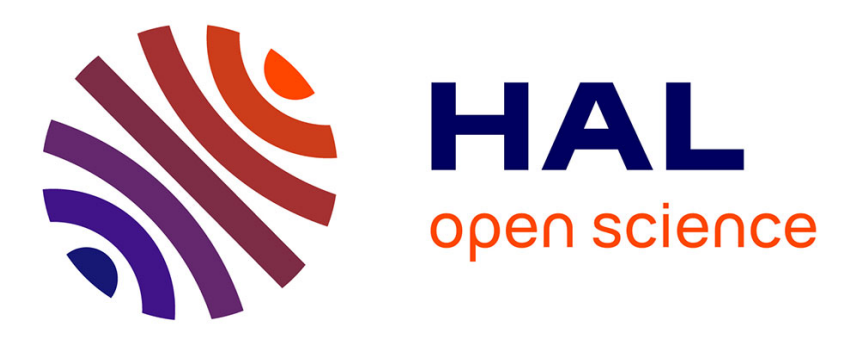

\title{
A model for the activity of silica along the carbonatite-kimberlite-mellilitite-basanite melt compositional joint
}

Malcolm Massuyeau, Emmanuel Gardès, Yann Morizet, Fabrice Gaillard

\section{To cite this version:}

Malcolm Massuyeau, Emmanuel Gardès, Yann Morizet, Fabrice Gaillard. A model for the activity of silica along the carbonatite-kimberlite-mellilitite-basanite melt compositional joint. Chemical Geology, 2015, 418, pp.206-216. 10.1016/j.chemgeo.2015.07.025 . insu-01181621

\section{HAL Id: insu-01181621 \\ https://hal-insu.archives-ouvertes.fr/insu-01181621}

Submitted on 30 Jul 2015

HAL is a multi-disciplinary open access archive for the deposit and dissemination of scientific research documents, whether they are published or not. The documents may come from teaching and research institutions in France or abroad, or from public or private research centers.
L'archive ouverte pluridisciplinaire HAL, est destinée au dépôt et à la diffusion de documents scientifiques de niveau recherche, publiés ou non, émanant des établissements d'enseignement et de recherche français ou étrangers, des laboratoires publics ou privés.

\section{(1)(1) $\$(0)$}

Distributed under a Creative Commons Attribution - NonCommercial - ShareAlikel 4.0 


\section{Accepted Manuscript}

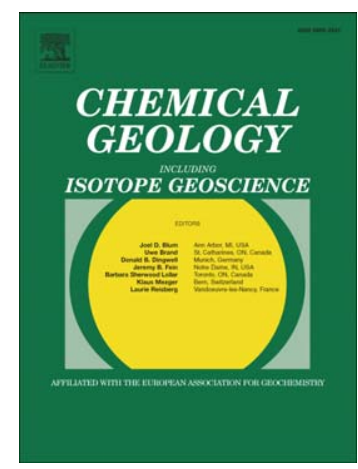

A model for the activity of silica along the carbonatite-kimberlite-mellilititebasanite melt compositional joint

Malcolm Massuyeau, Emmanuel Gardés, Yann Morizet, Fabrice Gaillard

PII:

S0009-2541(15)00355-1

DOI:

doi: 10.1016/j.chemgeo.2015.07.025

Reference: CHEMGE 17653

To appear in: $\quad$ Chemical Geology

Received date: 15 May 2014

Revised date: $\quad 16$ July 2015

Accepted date: 21 July 2015

Please cite this article as: Massuyeau, Malcolm, Gardés, Emmanuel, Morizet, Yann, Gaillard, Fabrice, A model for the activity of silica along the carbonatitekimberlite-mellilitite-basanite melt compositional joint, Chemical Geology (2015), doi: 10.1016/j.chemgeo.2015.07.025

This is a PDF file of an unedited manuscript that has been accepted for publication. As a service to our customers we are providing this early version of the manuscript. The manuscript will undergo copyediting, typesetting, and review of the resulting proof before it is published in its final form. Please note that during the production process errors may be discovered which could affect the content, and all legal disclaimers that apply to the journal pertain. 


\title{
A model for the activity of silica along the carbonatite- kimberlite-mellilitite-basanite melt compositional joint
}

\author{
Malcolm Massuyeau ${ }^{1}$, Emmanuel Gardés $^{2}$, Yann Morizet $^{1,3}$, and Fabrice Gaillard ${ }^{1}$ \\ ${ }^{1}$ ISTO, 7327 Université d’Orléans-CNRS-BRGM, 1A rue de la Férollerie, 45071 Orléans cedex 2, France \\ ${ }^{2}$ CEA-CNRS-ENSICAEN-Université de Caen Basse Normandie, CIMAP, UMR 6252, BP 5133, 14070 Caen, \\ France \\ ${ }^{3}$ Université de Nantes, Nantes Atlantique Universités, Laboratoire de Planétologie et Géodynamique de Nantes
}

\begin{abstract}
Carbon dioxide and water, being present in the Earth's mantle at concentration levels of tens to hundreds of ppm, greatly lower the peridotite solidus temperature and drastically modify the composition of produced melts. The presence of $\mathrm{CO}_{2}$ produces silica-poor, carbonate-rich liquids at the onset of melting, and these liquids shift toward silica rich compositions as the degree of melting increases. Numerous geochemical observations and experimental studies have revealed the complexity of the transition between carbonate-rich and silicate-rich melts. It is characterized by a strongly non-linear evolution and, under specific conditions, by immiscibility. To better constrain this transition, we have used the thermodynamic activity of silica as a probe of the mixing properties between molten carbonate and molten silicate. The activity of silica $\left(\mathrm{a}_{\mathrm{SiO}_{2}(\mathrm{l})}\right)$ was calculated for a large number of experimental liquids from two equilibria: olivine-orthopyroxene-melt and immiscible silicate-rich melt-carbonate-rich melt (491 data points ranging from 1 to $14 \mathrm{GPa}$ and 1090 to $1800^{\circ} \mathrm{C}$ ). We modeled $\mathrm{a}_{\mathrm{SiO}_{2}(\mathrm{l})}$ during incipient melting of the peridotite in presence of $\mathrm{CO}_{2}$ with a generalized Margules function. Our model well reproduces the silica activity-composition relationships of the experimental database, and can be used to predict the silica content of the melts coexisting with olivine and orthopyroxene. We show that water content and $\mathrm{Ca} / \mathrm{Mg}$ ratio in the melts have an important influence on the $\mathrm{a}_{\mathrm{SiO}_{2}(\mathrm{l})}$. In contrast to a recent empirical model (Dasgupta et al., 2013), the analysis of the experimental database reveals that the transition from carbonate to silicate melt with decreasing depth should occur abruptly in oceanic mantle. Our model predict that carbonatitic melts with $\sim 5 \mathrm{wt}$.\% $\mathrm{SiO}_{2}$ can be stabilized from $\sim 150 \mathrm{~km}$ depth, at the onset of incipient melting by "redox melting", up to $\sim 75 \mathrm{~km}$, above which the liquid evolves abruptly to a carbonated silicate composition ( $\left.>\sim 25 \mathrm{wt} . \% \mathrm{SiO}_{2}\right)$. In the cratonic mantle lithosphere, our model predicts that carbonatitic melts are prevailing up to shallow depth, and conflicts the recent model (Russell et al., 2012) of $\mathrm{CO}_{2}$-saturation triggered by orthopyroxene assimilation during kimberlite ascent.
\end{abstract}


Transition Carbonate-silicate mantle melt model Massuyeau et al. 2015

Keywords: incipient partial melting; carbonate-silicate melt transition; thermodynamic model; silica activity; ridge adiabat; immiscibility 


\section{Introduction}

Partial melting in the Earth's mantle is a key process in the global geodynamics since it produces the igneous rocks constituting the continental and oceanic crusts and it most likely gives rise to the geophysical signal of mantle mechanical weakening (Green and Liebermann, 1976; Presnall and Gudfinnsson, 2005; Holtzman and Kohlstedt, 2007; Gaillard et al., 2008; Hirschmann, 2010; Stagno et al., 2013; Sifré et al., 2014). Experimental petrology provides a key step in addressing the impact of mantle melting on global geodynamics, but the development of models capable of interpolating and extrapolating these data is mandatory. Such models must allow defining 1) the pressure-temperature location of the peridotite solidus and 2) the composition of the partial melts formed at a given pressure, temperature and bulk composition. Ghiorso and co-workers (Ghiorso et al., 1983; Ghiorso and Sack, 1995) have pioneered the numerical modelling of liquid-solid phase equilibria applied to magmatic systems, and this methodology has subsequently been extended to mantle melting (Hirschmann et al., 1998; Asimow et al., 2004).

The presence of volatiles species, water $\left(\mathrm{H}_{2} \mathrm{O}\right)$ and carbon dioxide $\left(\mathrm{CO}_{2}\right)$, is long known from experimental petrology to greatly affect both solidus and composition of partial melts produced in the mantle (Wyllie and Huang, 1976; Olafsson and Eggler, 1983; Taylor and Green, 1988; Wallace and Green, 1988; Thibault et al., 1992; Dasgupta and Hirschmann, 2006; Jakobsson and Holloway, 2008; Hirschmann, 2010; Rohrbach and Schmidt, 2011; Dasgupta, 2013; Tumiati et al., 2013; Ghosh et al., 2014; Hammouda \& Keshav, 2015). In particular, volatiles, being present in the Earth's mantle at low concentration levels, give rise to incipient melting, which is the formation of small melt fractions being stable in a large pressure-temperature domain (Fig.1). Modelling incipient melting in the presence of $\mathrm{CO}_{2}$ is particularly challenging because it produces carbonate-rich liquid compositions at low temperature, which evolve toward basaltic compositions with increasing temperature or decreasing pressure. The transition between carbonate-dominated and silicate-dominated melts coexisting with a peridotite/eclogite assemblage is rather well constrained by experimental petrology. However, the different experimental surveys on various chemical systems (quaternary to multicomponent) reveal a complex behaviour. The transition from carbonate melt to silicate melt is generally strongly non-ideal, and can show, under specific conditions, a miscibility gap between the two types of liquids.

In simple carbonated (CMAS- $\mathrm{CO}_{2}$ ) peridotite systems, carbonate-silicate liquids immiscibility has been reported (Novella et al., 2014). In quasi-natural systems, the transition between ionic carbonate melts (Jones et al., 2013) and polymerized silicate melts (i.e. $\mathrm{Q}^{\mathrm{n}}$ species, Mysen, 1999) seems to be continuous (miscible) although the change in melt chemistry is abrupt, and this transition becomes increasingly sharp with decreasing pressure. For example, at $3 \mathrm{GPa}$, the silica content of the liquid coexisting with a peridotite evolves from less than $10 \mathrm{wt} . \%$ (carbonatitic melt) to more than $25 \mathrm{wt} . \%$ (carbonate-rich silicate melt) from 1325 to $1350^{\circ} \mathrm{C}$ (Dasgupta et al., 2007). With increasing pressure, the carbonate to silicate melt transition is smoother possibly because of a higher $\mathrm{CO}_{2}$ solubility in the silicate melt (Brey and Green, 1976; Morizet et al., 2002; Guillot and Sator, 2011). The carbonate-silicate melt transition is 
also strongly dependent on the chemistry of the system. At a given pressure and temperature, the melt in equilibrium with a peridotite can be silica-poor $\left(<10 \mathrm{wt} . \% \mathrm{SiO}_{2}\right)$ in an alkali-free system and becomes richer in silica $\left(>15 \mathrm{wt} . \% \mathrm{SiO}_{2}\right)$ if alkalis are present (Moore, 2012).

Immiscibility between carbonate-rich and silicate-rich melts was reported in carbonated eclogitic compositions (Hammouda, 2003; Dasgupta et al., 2006; Tsuno and Dasgupta, 2011; Kiseeva et al., 2012). At $3 \mathrm{GPa}$, Dasgupta et al. (2006) interpreted the coexistence of both melts by the lower melting temperature of silicate in the eclogitic system compared to the peridotitic system; low temperature tends to favour immiscibility (Brooker and Kjarsgaard, 2011). The lower silicate solidi for the eclogitic bulk composition are related to the lower Mgnumbers and higher alkali contents (Kogiso et al., 2004), which may also impact the miscibility gap. For example, Kiseeva et al. (2012) observed immiscibility at 3.5 and $5.5 \mathrm{GPa}$, that they attributed to the addition of $\mathrm{H}_{2} \mathrm{O}$ and $\mathrm{K}_{2} \mathrm{O}$. Chemical composition of the melts (alkalis, $\mathrm{H}_{2} \mathrm{O}, \mathrm{MgO}$ ), temperature, and pressure have therefore complex and interrelated effects on the carbonate-silicate transition.

Several models address the $\mathrm{H}_{2} \mathrm{O}$-induced incipient mantle melting (Asimow and Langmuir, 2003; Katz et al., 2003; Hirschmann et al., 2009). The incorporation of $\mathrm{CO}_{2}$ in the systems was modelled in more recent studies (Dasgupta and Hirschmann, 2010; Hirschmann, 2010; Dasgupta et al., 2013). These empirical models are based on limited databases and are hardly applicable out of their range of calibration. In this study, we use the thermodynamic activity of $\mathrm{SiO}_{2}$ as a probe of the mixing properties between molten carbonate (carbonatite) and molten silicate (basalt). The activity of silica in the melts $\left(\mathrm{a}_{\mathrm{SiO}_{2}(\mathrm{l})}\right)$ is a powerful probe to characterize melts and their evolution with temperature, pressure and compositional variations as pioneered by Carmichael et al. (1970) in the case of silicate melts. This approach was also developed for carbonate melts (Barker, 2001; Luth, 2009). These studies explained the methodology of calculation of $\mathrm{a}_{\mathrm{SiO}_{2}(\mathrm{l})}$ but did not compare the evolution of the $\mathrm{a}_{\mathrm{SiO}_{2}(\mathrm{l})}$ relative to its actual fraction of silica determined by phase equilibria studies (i.e., $\mathrm{a}_{i}=\mathrm{X}_{i} \cdot \gamma_{i}$, with a, the activity, $X$, the molar fraction and $\gamma$, the activity coefficient).

We compiled a large database of equilibria involving carbonate melts with an important chemical diversity ranging from quaternary to quasi-natural systems, and with pressure and temperature ranging from 1 to $14 \mathrm{GPa}$ and 1090 to $1800^{\circ} \mathrm{C}$ (Fig. 1; Table 1). We considered two type of equilibrium: (i) coexistence of melt with olivine and orthopyroxene, and (ii) immiscible carbonate-rich and silicate-rich melts. We develop a thermodynamic model, based on the Margules formalism (Ghiorso et al., 1983; Ghiorso and Sack, 1995; Ghiorso et al., 2002; Green et al., 2012a). Using oxide components, this formalism is used to calculate the $\mathrm{a}_{\mathrm{SiO}_{2}(\mathrm{l})}$ during incipient melting of the peridotite in presence of $\mathrm{CO}_{2}$ in the system $\mathrm{SiO}_{2}-\mathrm{TiO}_{2}$ $\mathrm{Al}_{2} \mathrm{O}_{3}-\mathrm{Cr}_{2} \mathrm{O}_{3}-\mathrm{FeO}-\mathrm{MnO}-\mathrm{CaO}-\mathrm{MgO}-\mathrm{Na}_{2} \mathrm{O}-\mathrm{K}_{2} \mathrm{O}-\mathrm{P}_{2} \mathrm{O}_{5}-\mathrm{H}_{2} \mathrm{O}-\mathrm{CO}_{2}$. Our model satisfactorily reproduces the activity-composition relationships of $\mathrm{SiO}_{2}$ in the 1-10 GPa pressure range and the $1100-1700^{\circ} \mathrm{C}$ temperature range, and can therefore be used to predict the silica content of $\mathrm{CO}_{2}$-bearing melts in the upper mantle. 


\section{Modelling}

\subsection{Experimental database}

The selected experimental database regroups 491 experimental melts from $\mathrm{CMS}-\mathrm{CO}_{2}$ to quasi-natural systems, at pressures and temperature ranging from 1 to $14 \mathrm{GPa}$ and 1090 to $1800^{\circ} \mathrm{C}$ (Table 1). The database includes hydrous experiments, as well as some volatile-free experiments (see Supplementary Information Part 1 for details on the determination of $\mathrm{CO}_{2}$ and $\mathrm{H}_{2} \mathrm{O}$ contents when both are present). We also performed additional experiments at $3 \mathrm{GPa}$ in order to better constrain the role of alkalis and $\mathrm{Ca} / \mathrm{Mg}$ on the miscibility gap (see Supplementary Information Part 2 for details on the experimental protocol and melt compositions). Note that experimental data in quasi natural systems bearing $\mathrm{K}_{2} \mathrm{O}, \mathrm{Na}_{2} \mathrm{O}, \mathrm{CO}_{2}$ and $\mathrm{H}_{2} \mathrm{O}$ together are rare (36 data points for the crystal-liquid equilibrium, 0 data point for the liquid-liquid equilibrium). Moreover, some experimental studies in presence of water were not included in the model due to the lack of chemical analyses, experimental conditions, difficulties to estimate the $\mathrm{CO}_{2}$ and $\mathrm{H}_{2} \mathrm{O}$ contents in the melt phase.

\subsection{Calculation of silica activities from thermodynamic database}

\subsubsection{Crystal-liquid equilibrium}

We consider melts in equilibrium with olivine and orthopyroxene and assume that the $\mathrm{a}_{\mathrm{SiO}_{2}(\mathrm{l})}$ in the melt is constrained by the equilibrium (e.g. Carmichael et al., 1970; Luth, 2009)

$\mathrm{Mg}_{2} \mathrm{SiO}_{4}+\mathrm{SiO}_{2}(l)=\mathrm{Mg}_{2} \mathrm{Si}_{2} \mathrm{O}_{6}$,

where $\mathrm{SiO}_{2}(\mathrm{l})$ is the silica component in the melt, $\mathrm{Mg}_{2} \mathrm{SiO}_{4}$ is the forsterite component in olivine and $\mathrm{Mg}_{2} \mathrm{Si}_{2} \mathrm{O}_{6}$ is the enstatite component in orthopyroxene.

At given $\mathrm{P}$ and $\mathrm{T}$, equilibrium implies

$\Delta G^{*}+R T \ln (K)=0$

where $\mathrm{R}$ is the universal gas constant $\left(8.314 \mathrm{~J} \cdot \mathrm{mol}^{-1} \cdot \mathrm{K}^{-1}\right), \Delta \mathrm{G}^{*}$ is the standard state Gibbs free energy of the reaction

$\Delta G^{*}=G_{M g_{2} \mathrm{Si}_{2} \mathrm{O}_{6}}^{*}-G_{\mathrm{Mg}_{2} \mathrm{SiO}_{4}}^{*}-G_{\mathrm{SiO}_{2}(l)}^{*}$,

$\mathrm{K}$ is the equilibrium constant

$K=a_{M g_{2} \mathrm{Si}_{2} \mathrm{O}_{6}} /\left(a_{\mathrm{SiO}_{2}(l)} a_{\mathrm{Mg}_{2} \mathrm{SiO}_{4}}\right)$,

$\mathrm{a}_{\mathrm{Mg}_{2} \mathrm{SiO}_{4}}$ and $\mathrm{a}_{\mathrm{Mg}_{2} \mathrm{Si}_{2} \mathrm{O}_{6}}$ are the activity of forsterite in olivine, and the activity of enstatite in orthopyroxene, respectively. The calculation of $\Delta \mathrm{G}^{*}$ was based on the thermodynamic database of Holland and Powell (2011) (see Supplementary Information Part 3). For enstatite, the distinction between 2 polymorphs, orthoenstatite and clinoenstatite, is considered, as a function of the pressure and temperature conditions (Ulmer and Stalder, 2001). Eq. (4) 
implies that, at a given pressure and temperature, the only way to vary the $\mathrm{a}_{\mathrm{SiO}_{2}(\mathrm{l})}$ is to vary the ratio of forsterite to enstatite activities. However, in all experiments, as well as in the mantle (production of small melt fractions by incipient melting should not modify the composition of olivine and orthopyroxene in terms of $\mathrm{Mg \#})$, this ratio can be considered constant compared to the variability of $\Delta \mathrm{G}^{*} /(\mathrm{R} \mathrm{T})$. Therefore $\mathrm{a}_{\mathrm{SiO}_{2}(\mathrm{l})}$ mainly varies as a function of pressure or temperature as an increase in temperature and a decrease of pressure will increase $\mathrm{a}_{\mathrm{SiO}_{2}(\mathrm{l})}$ (see Fig. S2).

In quasi-natural systems, a non-ideal solid solution is often considered for olivine and orthopyroxene (Ghiorso et al., 1983; Stagno and Frost, 2010; Green et al., 2012b); however in the present work we chose to use ideal solid solutions definition. This approximation is relatively safe due to the predominant magnesian character in the data and will only introduce minor deviations on $\mathrm{a}_{\mathrm{SiO}_{2}(\mathrm{l})}$ (see Supplementary Information Part 5). Consequently, their activities are given by

$a_{M_{2} S_{i O}}=\left(X_{M g}^{M 1, F o} X_{M g}^{M 2, F o}\right)$

and

$a_{M g_{2} S i_{2} O_{6}}=\left(X_{M g}^{M 1, E n s} X_{M g}^{M 2, E n s}\right)$,

where $\mathrm{X}_{\mathrm{Mg}}^{\mathrm{M} 1, \mathrm{Fo}}$ and $\mathrm{X}_{\mathrm{Mg}}^{\mathrm{M} 2, \mathrm{Fo}}$ are the mole fraction of $\mathrm{Mg}$ in the $\mathrm{M} 1$ site and the $\mathrm{M} 2$ site of forsterite, respectively, and $\mathrm{X}_{\mathrm{Mg}}^{\mathrm{M} 1, \mathrm{Ens}}$ and $\mathrm{X}_{\mathrm{Mg}}^{\mathrm{M} 2 \text {,Ens }}$ are the mole fraction of $\mathrm{Mg}$ in the M1 site and the M2 site of enstatite, respectively. Following Ghiorso and Carmichael (1980), Hirschmann (1991) and Ghiorso et al. (1983), the site mole fractions are estimated by:

$X_{M g}^{M 1, F o}=n_{M g}^{M 1, F o} /\left(n_{N i}+n_{F e}^{M 1, F o}+n_{M g}^{M 1, F o}\right)$,

$X_{M g}^{M 2, F o}=n_{M g}^{M 2, F o} /\left(n_{C a}+n_{M n}+n_{F e}^{M 2, F o}+n_{M g}^{M 2, F o}\right)$,

$X_{M g}^{M 1, E n s}=n_{M g}^{M 1, E n s} /\left(n_{T i}+0.5 n_{A l}+n_{C r}+n_{F e}^{M 1, E n s}+n_{M g}^{M 1, E n s}\right)$,

and

$X_{M g}^{M 2, E n s}=n_{M g}^{M 2, E n s} /\left(n_{C a}+n_{N a}+n_{M n}+n_{F e}^{M 2, E n s}+n_{M g}^{M 2, E n s}\right)$,

where

$n_{M g}^{M 1, F o}=\left(n_{M g} /\left(2\left(n_{M g}+n_{F e}\right)\right)\right)\left(n_{C a}+n_{M n}+n_{F e}+n_{M g}-n_{N i}-n_{T i}-0.5 n_{A l}\right)$
$n_{M g}^{M 1, E n s}=\left(n_{M g} /\left(2\left(n_{M g}+n_{F e}\right)\right)\right)\left(n_{C a}+n_{M n}+n_{N a}+n_{F e}+n_{M g}-n_{C r}-n_{T i}-\right.$
$0.5 n A l, \quad(12)$
$n_{F e}^{M 1, F o}=n_{M g}^{M 1, F o}\left(1 /\left(n_{M g} /\left(n_{M g}+n_{F e}\right)\right)-1\right)$,
$n_{F e}^{M 1, E n s}=n_{M g}^{M 1, E n s}\left(1 /\left(n_{M g} /\left(n_{M g}+n_{F e}\right)\right)-1\right)$, 
$n_{M g}^{M 2, F o}=n_{M g}-n_{M g}^{M 1, F o}$,

$n_{M g}^{M 2, E n s}=n_{M g}-n_{M g}^{M 1, E n s}$,

$n_{F e}^{M 2, F o}=n_{F e}-n_{F e}^{M 1, F o}$

and

$n_{F e}^{M 2, E n s}=n_{F e}-n_{F e}^{M 1, E n s}$.

The silica activity in the melt is given by:

$\ln \left(a_{\mathrm{SiO}_{2}(l)}\right)=\left(\Delta G^{*} /(R T)\right)+\ln \left(\left(X_{M g}^{M 1, E n s} X_{M g}^{M 2, E n s}\right) /\left(X_{M g}^{M 1, F o} X_{M g}^{M 2, F o}\right)\right)$

Therefore the silica activity coefficient $\gamma_{\mathrm{SiO}_{2}(\mathrm{l})}$ writes

$R T \ln \left(\gamma_{\mathrm{SiO}_{2}(l)}\right)_{\exp }=$
$\Delta G^{*}+R T \ln \left(\left(X_{M g}^{M 1, E n s} X_{M g}^{M 2, E n s}\right) /\left(X_{M g}^{M 1, F o} X_{M g}^{M 2, F o}\right)\right)-R T \ln \left(X_{S_{i O}(l)}\right)$

$\mathrm{SiO}_{2}$ activity-composition relationships for the experimental crystal-liquid equilibria are reported in Figs. 2A-E, $2 \mathrm{G}$.

\subsubsection{Liquid-liquid equilibrium}

When two immiscible silicate-rich melt (SL) and carbonate-rich melt (CL) coexist at equilibrium, their $\mathrm{a}_{\mathrm{SiO}_{2}(\mathrm{l})}$ is identical, with

$a_{S^{S O} O_{2}(l)}^{S L}=a_{S^{2} O_{2}(l)}^{C L}$

Then, we can write

$X_{\mathrm{SiO}_{2}(l)}^{S L} \gamma_{\mathrm{SiO}_{2}(l)}^{\mathrm{SL}}=X_{\mathrm{SiO}_{2}(l)}^{\mathrm{CL}} \gamma_{\mathrm{SiO}_{2}(l)}^{\mathrm{CL}}$

or

$R T \ln \left(\gamma_{\mathrm{SiO}_{2}(l)}^{\mathrm{CL}} / \gamma_{\mathrm{SiO}_{2}(l)}^{S L}\right)_{\text {exp }}=R T \ln \left(X_{\mathrm{SiO}_{2}(l)}^{S L} / X_{\mathrm{SiO}_{2}(l)}^{C L}\right)$

$\mathrm{RT} \ln \left(\gamma_{\mathrm{SiO}_{2}(\mathrm{l})}^{\mathrm{CL}} / \gamma_{\mathrm{SiO}_{2}(\mathrm{l})}^{\mathrm{SL}}\right)_{\exp }$-composition relationships for the experimental liquid-liquid equilibria are reported in Fig. $2 \mathrm{H}$.

\subsection{Model for the activity coefficient $\gamma_{\mathrm{SiO}_{2}(l)}$}

We describe the chemical space between carbonate and silicate end-members using oxide components $\left(\mathrm{SiO}_{2}, \mathrm{TiO}_{2}, \mathrm{Al}_{2} \mathrm{O}_{3}, \mathrm{Cr}_{2} \mathrm{O}_{3}, \mathrm{FeO}, \mathrm{MnO}, \mathrm{CaO}, \mathrm{MgO}, \mathrm{Na}_{2} \mathrm{O}, \mathrm{K}_{2} \mathrm{O}, \mathrm{P}_{2} \mathrm{O}_{5}, \mathrm{H}_{2} \mathrm{O}, \mathrm{CO}_{2}\right.$ ) (Richet and Bottinga, 1985). Following DeCapitani and Kirschen (1998), we relate $\gamma_{\mathrm{SiO}_{2}(\mathrm{l})}$ to the excess Gibbs free energy of the liquid $G_{(l)}^{X S}$ as follows: 
$R T \ln \left(\gamma_{S_{i O}(l)}\right)_{c a l c}=$
$G_{(l)}^{X S}+\left(\partial G_{(l)}^{X S} / \partial X_{S i O_{2}(l)}\right)_{p, T, X_{k}, k \neq \operatorname{SiO}_{2}(l)}-\sum_{j=1}^{n c} X_{j}\left(\partial G_{(l)}^{X S} / \partial X_{j}\right)_{p, T, X_{k}, k \neq j}$,

where $n c$ is the number of components. $\mathrm{G}_{(1)}^{\mathrm{XS}}$ was taken as a generalized Margules function in which the $\mathrm{SiO}_{2}-\mathrm{CO}_{2}$ interaction is modelled by a third-degree polynomial (asymmetric part) using two Margules parameters, $\mathrm{W}_{\mathrm{SiO}_{2}-\mathrm{CO}_{2}}^{\mathrm{a}}$ and $\mathrm{W}_{\mathrm{SiO}_{2}-\mathrm{CO}_{2}}^{\mathrm{b}}$, in order to account for the strong non-ideality between these two components. The interaction between the other selected binaries is modelled by a second-degree polynomial (symmetric part) with single Margules parameters $\mathrm{W}_{\mathrm{i}-\mathrm{j}}$. The Margules parameters are assumed to be independent on pressure and temperature. The construction of a more complete thermodynamic formulation, e.g. including the activity coefficient of all components, would certainly be worthwhile but is beyond the scope of the present study.

Preliminary calculations were performed in order to select the terms of $\mathrm{G}^{\mathrm{XS}}$ relevant for calculating $\gamma_{\mathrm{SiO}_{2}(\mathrm{l})}$. We rejected the binaries having (1) absolute values of the correlation coefficient with RT $\ln \left(\gamma_{\mathrm{SiO}_{2}(\mathrm{l})}\right)$ lower than 0.2 (see Supplementary Table S4), and (2) $\mathrm{W}_{\mathrm{i}-\mathrm{j}} \mathrm{S}$ with uncertainties higher than $50 \%$ (see Table 2). The selected $G_{(1)}^{\mathrm{XS}}$ function is

$$
\begin{aligned}
& G_{(l)}^{X S}=W_{\mathrm{SiO}_{2}-\mathrm{CO}_{2}}^{a} X_{\mathrm{SiO}_{2}}^{2} X_{\mathrm{CO}_{2}}+W_{\mathrm{SiO}_{2}-\mathrm{CO}_{2}}^{b} X_{\mathrm{SiO}_{2}} X_{\mathrm{CO}_{2}}^{2}+W_{\mathrm{Al}_{2} \mathrm{O}_{3}-\mathrm{SiO}_{2}} X_{\mathrm{Al}_{2} \mathrm{O}_{3}} X_{\mathrm{SiO}_{2}}+
\end{aligned}
$$

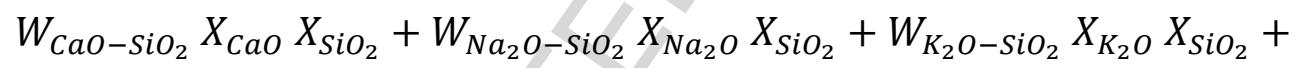

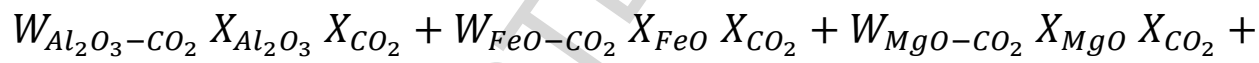

$$
\begin{aligned}
& W_{\mathrm{Na}_{2} \mathrm{O}-\mathrm{CO}_{2}} X_{\mathrm{Na}_{2} \mathrm{O}} X_{\mathrm{CO}_{2}}+W_{\mathrm{K}_{2} \mathrm{O}-\mathrm{CO}_{2}} X_{\mathrm{K}_{2} \mathrm{O}} X_{\mathrm{CO}_{2}}+W_{\mathrm{H}_{2} \mathrm{O}-\mathrm{CO}_{2}} X_{\mathrm{H}_{2} \mathrm{O}} X_{\mathrm{CO}_{2}}+ \\
& W_{\mathrm{Al}_{2} \mathrm{O}_{3}-\mathrm{FeO}} \mathrm{X}_{\mathrm{Al}_{2} \mathrm{O}_{3}} \mathrm{XFeO}_{\mathrm{FeO}}+W_{\mathrm{Al}_{2} \mathrm{O}_{3}-\mathrm{MgO}} X_{\mathrm{Al}_{2} \mathrm{O}_{3}} X_{\mathrm{MgO}}+W_{\mathrm{FeO}-\mathrm{CaO}} X_{\mathrm{FeO}} X_{\mathrm{CaO}}+ \\
& W_{\mathrm{CaO}-\mathrm{Na}_{2} \mathrm{O}} X_{\mathrm{CaO}} X_{\mathrm{Na}_{2} \mathrm{O}}
\end{aligned}
$$

which yields, when substituted in Eq. (24),

$$
\begin{aligned}
& R T \ln \left(\gamma_{\mathrm{SiO}_{2}(l)}\right)_{\mathrm{calc}}=W_{\mathrm{SiO}_{2}-\mathrm{CO}_{2}}^{a}\left(2 X_{\mathrm{SiO}_{2}} X_{\mathrm{CO}_{2}}-2 X_{\mathrm{SiO}_{2}}^{2} X_{\mathrm{CO}_{2}}\right)+W_{\mathrm{SiO}_{2}-\mathrm{CO}_{2}}^{b}\left(X_{\mathrm{CO}_{2}}^{2}-\right. \\
& 2 \mathrm{XSiO}_{2} \mathrm{XCO}_{2} 2+\mathrm{WAl}_{2} \mathrm{O}_{3}-\mathrm{SiO}_{2} \mathrm{XAl}_{2} \mathrm{O}_{3} 1-\mathrm{XSiO}_{2}+\mathrm{WCaO}_{\mathrm{ClO}} \mathrm{SiO}_{2} \mathrm{CaO} \\
& \left(1-X_{\mathrm{SiO}_{2}}\right)+W_{\mathrm{Na}_{2} \mathrm{O}-\mathrm{SiO}_{2}} X_{\mathrm{Na}_{2} \mathrm{O}}\left(1-X_{\mathrm{SiO}_{2}}\right)+W_{\mathrm{K}_{2} \mathrm{O}-\mathrm{SiO}_{2}} X_{\mathrm{K}_{2} \mathrm{O}}\left(1-X_{\mathrm{SiO}_{2}}\right)-
\end{aligned}
$$

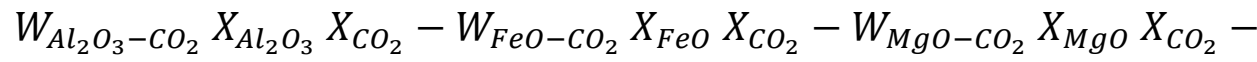

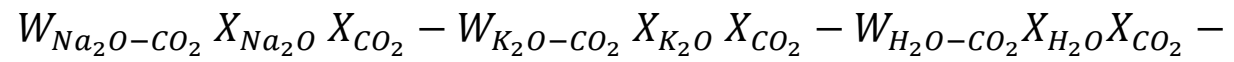

$$
\begin{aligned}
& W_{\mathrm{Al}_{2} \mathrm{O}_{3}-\mathrm{FeO}} X_{\mathrm{Al}_{2} \mathrm{O}_{3}} X_{\mathrm{FeO}}-W_{\mathrm{Al}_{2} \mathrm{O}_{3}-\mathrm{MgO}} X_{\mathrm{Al}_{2} \mathrm{O}_{3}} X_{\mathrm{MgO}}-W_{\mathrm{FeO}-\mathrm{CaO}} X_{\mathrm{FeO}} X_{\mathrm{CaO}}- \\
& W_{\mathrm{CaO}-\mathrm{Na}_{2} \mathrm{O}} X_{\mathrm{CaO}} X_{\mathrm{Na}_{2} \mathrm{O}} \text {. (26) }
\end{aligned}
$$

The general formula for the uncertainty propagation on $\mathrm{a}_{\mathrm{SiO}_{2}(\mathrm{l})}$ is

$$
\begin{aligned}
& \delta_{a_{S i O_{2}(l)}}^{2}=\left(\partial a_{S i O_{2}(l)} / \partial\left(\Delta G^{*} /(R T)\right)\right)^{2} \delta_{\left[\Delta G^{*} /(R T)\right]}^{2}+\left(\partial a_{S i O_{2}(l)} / \partial a_{M g_{2} S i_{2} O_{6}}\right)^{2} \delta_{a_{M g_{2} S i_{2} O_{6}}^{2}}^{2}+ \\
& \left(\partial a_{\mathrm{SiO}_{2}(l)} / \partial a_{\mathrm{Mg}_{2} \mathrm{SiO}_{4}}\right)^{2} \delta_{\mathrm{Mg}_{2} \mathrm{SiO}_{4}}^{2} .
\end{aligned}
$$


The uncertainty on $\Delta \mathrm{G}^{*} /(\mathrm{R} \mathrm{T})$ is predominant relative to the uncertainties on $\mathrm{a}_{\mathrm{Mg}_{2} \mathrm{Si}_{2} \mathrm{O}_{6}}$ and

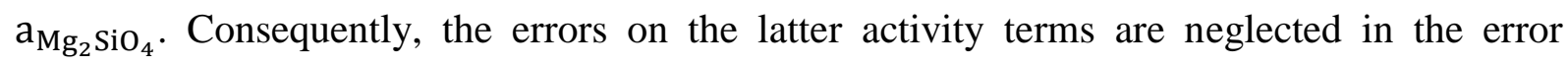
propagation ( $10-15 \%$ of the actual error on $\mathrm{a}_{\mathrm{SiO}_{2}(\mathrm{l})}$ calculated with only $\left.\Delta \mathrm{G}^{*} /(\mathrm{R} \mathrm{T})\right)$.

The uncertainty on $\Delta \mathrm{G}^{*} /(\mathrm{R} \mathrm{T})$ is calculated by propagating experimental $(\mathrm{P}, \mathrm{T})$ and thermodynamic (reference states $\mathrm{H}_{\mathrm{i}}$ ) uncertainties (see Supplementary Information Part. 3). Unless specified by the author, we consider an error of $12^{\circ} \mathrm{C}$ (Dasgupta et al., 2005) and 0.1 $\mathrm{GPa}$ for piston-cylinder experiments (Dasgupta et al., 2013), and an error of $30^{\circ} \mathrm{C}$ (Keshav et al., 2011) and 0.3 GPa for multi-anvil experiments (Dasgupta et al., 2013). This typically results in uncertainties on $\mathrm{a}_{\mathrm{SiO}_{2}(\mathrm{l})}$ of about 10-15\% (Figs. 2-3). In most cases, the uncertainty on the silica content is given by the experimental studies (see Fig. S5A). When the error on the silica content is unknown, we approximate the uncertainties using an exponential function which provides a representative error within the investigated $\mathrm{SiO}_{2}$ content (Fig. S5A; see Supplementary Information Part $4 \mathrm{~b}$ ). Details on the calculation of uncertainties are reported in the Supplementary Information Parts 4.

Some biases tarnish the model, principally due to the definition of the $G_{(1)}^{X S}$. Firstly, the Margules parameters are only calibrated via the $\mathrm{RT} \ln \left(\gamma_{\mathrm{SiO}_{2}(\mathrm{l})}\right)$ (Eq. 24), which implies a partial description of the melt mixing properties. Secondly, the choice of ideal interaction between some components for the $G_{(1)}^{X S}$ implies corresponding directions in the compositional space are not well constrained.

Nevertheless, the strength of the model is the incorporation of data points for the immiscibility between silicate and carbonate liquids. Indeed, this equilibrium only constrains the mixing properties of the melts, independently of the standard states (Berman and Brown, 1984).

\subsection{Optimization}

The Margules parameters were optimized for the activity coefficients calculated according to Eq. (26) to best match the experimental activity coefficients given by Eqs. (20) and (23), i.e. by minimizing

$\sum_{i=1}^{n d 1}\left(\left(\left(R T \ln \left(\gamma_{\mathrm{SiO}_{2}(l)}\right)\right)_{\text {calc } i}-\left(R T \ln \left(\gamma_{\mathrm{SiO}_{2}(l)}\right)\right)_{\exp i}\right) / \delta_{\left(R T \ln \left(\gamma_{\mathrm{SiO}_{2}(l)}\right)\right)_{\text {exp } i}}\right)^{2}+$ $\sum_{i=1}^{n d 2}\left(\left(\left(R T \ln \left(\gamma_{\mathrm{SiO}_{2}(l)}^{\mathrm{CL}} / \gamma_{\mathrm{SiO}_{2}(l)}^{S L}\right)\right)_{\text {calc } i}-\left(R T \ln \left(\gamma_{\mathrm{SiO}_{2}(l)}^{\mathrm{CL}} / \gamma_{\mathrm{SiO}_{2}(l)}^{S L}\right)\right)_{\text {exp } i}\right) / \delta_{\left(R T \ln \left(\gamma_{\mathrm{SiO}_{2}(l)}^{C L} / \gamma_{\mathrm{SiO}_{2}(l)}^{S L}\right)\right)_{\text {exp } i}}\right)^{2}$ , (28)

where the sum is done over all the crystal-liquid equilibria $(n d l=400)$ and the liquid-liquid equilibria $(n d 2=91)$. 
In addition to the Margules parameters, we also refined the standard volume of reaction because the volume of $\mathrm{SiO}_{2}(1)$ has only been calibrated at low pressures ( $<6 \mathrm{GPa}$ ) in the database of Holland and Powell (2011) (see Supplementary Information Part 3; Fig. S4).

The optimized Margules parameters for the $G_{(1)}^{X S}$ function (Eq. 25) are reported with associated uncertainties in Table 2. The calculated $\mathrm{X}_{\mathrm{SiO}_{2}(\mathrm{l})}$ for crystal-liquid equilibria and $\gamma_{\mathrm{SiO}_{2}}^{\mathrm{CL}} / \gamma_{\mathrm{SiO}_{2}}$ for liquid-liquid equilibria compares fairly well with the experimental data (Fig. 3). Deviations mostly compare to experimental uncertainties, and are $15 \%$ on average (Fig. S5B). Our model is reliable for $1-10 \mathrm{GPa}$ and $1100-1700^{\circ} \mathrm{C}$, since most of experiments lie in this range (Fig. 1), and therefore covers most of the upper mantle conditions without extrapolation.

\section{Discussion}

\subsection{Observed versus predicted effect of pressure, temperature and bulk composition on $a_{\mathrm{SiO}_{2}}$} in magmatic liquids

As expected, $\mathrm{a}_{\mathrm{SiO}_{2}(\mathrm{l})}$ globally increases with the silica concentration of the experimental melts (e.g. Fig. 2A). At highest $\mathrm{SiO}_{2}$ content (> 30 wt.\%), mixing is close to ideal although small negative deviations are observed. However, a strong positive deviation from ideal mixing is observed in the carbonate part $\left(<\sim 20 \mathrm{wt} . \% \mathrm{SiO}_{2}\right)$, together with a broadening of the activity ranges. This is even more striking from the evolution of the $\gamma_{\mathrm{SiO}_{2}(\mathrm{l})}$ as a function of silica content (Fig S6), which is about 1 for 30-50 wt. $\% \mathrm{SiO}_{2}$ and strongly increases up to more than 10 for $<30 \mathrm{wt}$. $\% \mathrm{SiO}_{2}$.

Activity decreases significantly as a function of pressure. This effect is especially pronounced in the most carbonate part, where $\mathrm{a}_{\mathrm{SiO}_{2}(\mathrm{l})}$ drops from $~ 0.3$ to 0.1 from 1 to $10 \mathrm{GPa}$ (Fig. 2A). On the other hand, no clear trend is observed with temperature but it is likely because it varies less than pressure among experiments (Fig. 2B). As shown in Fig. 2C, experiments performed with significant amount of water (>0.2 wt.\% bulk) have significantly lower $\mathrm{SiO}_{2}$ activities than nominally dry experiments, especially in the carbonate part. Water therefore makes carbonate melts closer to ideal mixture.

There is no discernible difference between CMAS and quasi-natural systems except for the carbonate part $\left(<\sim 20\right.$ wt. $\left.\mathrm{SiO}_{2}\right)$, where CMAS systems display higher deviations from ideal mixing (Fig. 2D). This mainly stems from higher $\mathrm{Ca} / \mathrm{Mg}$ ratios which are found to strongly enhance positive deviations from ideal mixing (Fig. 2E). Actually, most of the range of the experimental data can be reproduced by our model by changing the $\mathrm{Ca} / \mathrm{Mg}$ ratio together with the water content (Fig. 4A). Interestingly, there is a strong dependence of the $\mathrm{Ca} / \mathrm{Mg}$ ratio on pressure in carbonate melts with $<20 \mathrm{wt} . \% \mathrm{SiO}_{2}$; the higher the pressure, the lower the $\mathrm{Ca} / \mathrm{Mg}$ ratio (Fig. 2F; Dalton and Wood, 1993). There is therefore a correspondence between pressure and the chemistry of the melts.

The weak variation of activities at intermediate $\mathrm{SiO}_{2}$ content (15-35 wt.\%), leading to the overall sigmoidal shape of the database (e.g. quasi-natural data on Fig. 2D) and which is 
reproduced by our model (e.g. Fig. 4A), implies that the transition from silicate to carbonate melt from high to low $\mathrm{a}_{\mathrm{SiO}_{2}(\mathrm{l})}$ occurs within a narrow range of activity. Importantly, as activity decreases with increasing pressure, this implies that melts change rather abruptly from silicate to carbonate compositions with depth when not accompanied by important change in temperature.

Moreover, the dependence of $\mathrm{a}_{\mathrm{SiO}_{2}(\mathrm{l})}$ on $\mathrm{X}_{\mathrm{SiO}_{2}(\mathrm{l})}$ may even reverse and be negative at intermediate $\mathrm{X}_{\mathrm{SiO}_{2}(l)}$, depending on melt composition. This is for instance visible for the CMAS data in figure 2D which globally have higher $\mathrm{Ca} / \mathrm{Mg}$ ratios, and this is also reproduced by our model for high $\mathrm{Ca} / \mathrm{Mg}$ ratios (Fig. 4A). This pattern is indicative of immiscibility between carbonate and silicate melts though, the whole surface of the Gibbs free energy of mixing is required to predict immiscibility. Ca-rich melts therefore strongly deviate from ideality and our model predict that immiscibility may occur at the highest enrichments, which is in consistency with the immiscibility of carbonated eclogitic systems (Dasgupta et al, 2006).

Alkalis also favor immiscibility. This is less apparent from crystal-liquid equilibrium data (Fig. 2G) because almost of these melts contain relatively small amount of alkalis $(<\sim 5-6$ wt.\%). However, the immiscible liquid-liquid equilibrium data, where high alkalis content were used (mostly $>\sim 5 \%$ ), clearly show that the miscibility gap increases with the $(\mathrm{Na}+\mathrm{K}) / \mathrm{Mg}$ ratio (Fig. $2 \mathrm{H})$. The favoring of immiscibility by alkalis is in line with the conclusion of Brooker and Kjarsgaard (2011), but it requires rather elevated alkalis content (Fig. 4B).

\subsection{Evolution of the melt along a ridge adiabat}

We applied our model to predict the evolution of the $\mathrm{SiO}_{2}$ content of incipient melts in the oceanic upper mantle (Fig. 5A). Calculations were performed from 60 to $300 \mathrm{~km}$ depth (2 to $10 \mathrm{GPa}$ ) along a ridge adiabat with a potential temperature $\mathrm{Tp}=1350^{\circ} \mathrm{C}$ (temperature at pressure of 1 bar in a adiabatic system), and assuming melt in equilibrium with olivine and orthopyroxene of pyrolitic composition. This calculation therefore remains in the range of calibration of our model. For this application, we propagated the uncertainties on the Margules parameters as reported in Table 2, and the uncertainties on the reference states $\mathrm{H}_{\mathrm{i}}$, which overall, produce the green envelop surrounding the dry curve (Fig. 5A). The silicate and carbonate melt end-members were taken similar to those of Dasgupta et al. (2013), but we consider additionally that the $\mathrm{Ca} / \mathrm{Mg}$ ratio in the carbonate end-member varies as a function of pressure as mentioned above and reported in Fig. 2F (see Supplementary Information Part 6 for calculation details). Similarly to Dasgupta et al. (2013), both end-members are dry.

In these conditions, the $\mathrm{a}_{\mathrm{SiO}_{2}(\mathrm{l})}-\mathrm{X}_{\mathrm{SiO}_{2} \text { (l) }}$ relationship predicted by our model presents a slope inversion as discussed above, so the evolution of melt composition is bounded by two limit cases between which immiscibility may occur. In the first case, the melt is carbonatitic between 300 and $110 \mathrm{~km}$ depth, with a nearly constant silica content of 3-5 wt.\%. At about $110 \mathrm{~km}$, the melt abruptly shifts from about 5 to $25-30 \mathrm{wt}$. $\% \mathrm{SiO}_{2}$ and progressively evolves 
to basanite type ( 45 wt. $\left.\% \mathrm{SiO}_{2}\right)$ at shallow depths. In the second case, the evolution is similar, but the sharp transition occurs at a shallower depth of $\sim 75 \mathrm{~km}$. The uncertainty on the transition and immiscibility between carbonate and silicate melt is therefore limited to a 40 $\mathrm{km}$ range, between $\sim 110$ and $75 \mathrm{~km}$ depth.

This abrupt transition is evidently different from the gradual transition yielded by ideal mixing, but also from that predicted by the model of Dasgupta et al. (2013) (Fig. 5A). While the silica contents of the melt calculated from our model are similar to those of Dasgupta et al. (2013) down to $\sim 110 \mathrm{~km}$ depth, the model of Dasgupta et al. (2013) predicts a gradual decrease of the melt $\mathrm{SiO}_{2}$ content at greater depth, being $\sim 25$ and $\sim 10$ wt.\% at 150 and 250 $\mathrm{km}$ depth, respectively. However, the model of Dasgupta et al. (2013) is extrapolated for pressures above $5 \mathrm{GPa}(\sim 150 \mathrm{~km})$. This extrapolation likely does not consider the decrease in $\mathrm{Ca} / \mathrm{Mg}$ of carbonate melts with increasing pressure (Fig. $2 \mathrm{~F}$ ). The conversion of their model in term of $\mathrm{a}_{\mathrm{SiO}_{2}(\mathrm{l})}-\mathrm{X}_{\mathrm{SiO}_{2}(\mathrm{l})}$ relationship is fairly well reproduced by our model in their experimental range of calibration when using their compositions (Fig. $4 \mathrm{C}$ for $\mathrm{X}_{\mathrm{SiO}_{2}(\mathrm{l})}>0.2$ ). However their extrapolation at lower $\mathrm{SiO}_{2}$ content significantly deviates from our calculation (even though performed with a constant $\mathrm{Ca} / \mathrm{Mg}$ ratio), and lies at the margin of the experimental database (Fig. 4C). Actually, even when using the composition of Dasgupta et al. $(2007,2013)$ and setting it constant with depth, our model still predicts an abrupt change to carbonate melts with $<\sim 5$ wt. $\% \mathrm{SiO}_{2}$ at $\sim 150 \mathrm{~km}$ depth.

We calculated the evolution of incipient melt along a ridge adiabat in presence of water (Fig. $5 \mathrm{~A}$; same pressure-temperature conditions as dry curve), with varying $\mathrm{H}_{2} \mathrm{O} / \mathrm{CO}_{2}$ ratio in the carbonate component: $0.1\left(1.92 \mathrm{wt} . \% \mathrm{H}_{2} \mathrm{O}\right.$ in the incipient carbonate melt at solidus, melt fraction $\mathrm{F}=0), 0.2\left(3.77\right.$ wt. $\left.\% \mathrm{H}_{2} \mathrm{O}\right)$ and $0.5\left(8.93\right.$ wt. $\left.\% \mathrm{H}_{2} \mathrm{O}\right)$. For instance, if a partition coefficient of 0.006 is considered (average partition coefficient in the pressure range from 2 to $10 \mathrm{GPa}$; Hirschmann et al., 2009), the corresponding water bulk content is $115 \mathrm{ppm}, 226 \mathrm{ppm}$ and $536 \mathrm{ppm}$, respectively. As mentioned earlier, the melt becomes more ideal in presence of water (e.g. Fig. 4A), therefore the transition from silicate melt to carbonate melt is less abrupt with increasing bulk water content and the potential immiscibility area is narrower than in the dry case. The immiscibility ranges from $20 \mathrm{~km}$ between 110 and $90 \mathrm{~km}$ depth for $\mathrm{H}_{2} \mathrm{O} / \mathrm{CO}_{2}=$ 0.2 , and disappears for $\mathrm{H}_{2} \mathrm{O} / \mathrm{CO}_{2}=0.5$. Considering different adiabatic P-T profiles also changes the depth of the transition, with carbonatitic melts being likely stable at $>\sim 60 \mathrm{~km}$ depth for $\mathrm{Tp}=1250^{\circ} \mathrm{C}$ and $>\sim 130 \mathrm{~km}$ depth $\mathrm{km}$ for $\mathrm{Tp}=1450^{\circ} \mathrm{C}$ (Fig. 5B). Thus higher temperatures tend to shift the melt composition toward higher silica contents.

The melting of $\mathrm{CO}_{2}$-bearing peridotite is not only defined by the pressure and temperature conditions, but it also depends on the speciation of carbon in depth. The oxidation state of the mantle combined with the equilibrium EMOD $\left(\mathrm{MgSiO}_{3}+\mathrm{MgCO}_{3}=\mathrm{Mg}_{2} \mathrm{SiO}_{4}+\mathrm{C}+\mathrm{CO}_{2}\right)$, defines the onset of incipient melting by "redox melting" between 120 and $150 \mathrm{~km}$ depth (Stagno et al., 2013). Therefore, incipient melting should not occur at depth exceeding 150 $\mathrm{km}$, though Rohrbach and Schmidt (2011) defined a greater depth for the redox melting (250 $\mathrm{km})$. In both cases, we calculate that the first liquids produced by redox melting are 
carbonatitic (< 10 wt.\% $\left.\mathrm{SiO}_{2}\right)$ conversely to Dasgupta et al. (2013) who claimed that melt at such depth must be much silica richer (>25 wt. \% $\left.\mathrm{SiO}_{2}\right)$.

\subsection{Evolution of the melt along a cratonic geotherm}

Russell et al. (2012) proposed that the assimilation of orthopyroxene in the cratonic mantle lithosphere is an efficient mechanism to exsolve a volatile-rich fluid phase by enriching in silica any rising carbonatitic melts: orthopyroxene assimilation at lithospheric depth is then suggested to provide sufficient buoyancy for rapid ascent of kimberlites. Russell et al. (2012) suggests that this assimilation drives the melt towards more silicic composition during the ascent (Fig. 5C), with an evolution for the $\mathrm{SiO}_{2}$ content from 5 to 20 wt.\% between 120 and $60 \mathrm{~km}$ depth.

We calculated the evolution of melt composition along a cratonic geotherm (modified from Lee et al., 2011; see Fig. S7) in Fig. 5C, keeping all other parameters the other calculation settings identical to Fig. 5A. Our calculation yields a decrease of the silica content in the cratonic lithosphere, from $\sim 2-6$ (dry or hydrous respectively) to $\sim 0 \mathrm{wt} \%$ between 200 and 60 $\mathrm{km}$ depth, implying that carbonatite melt rising through the cratonic lithosphere cannot assimilate orthopyroxene since the opposite is expected from a thermodynamic point of view: orthopyroxene must crystallize. Even though our model is here applied outside the temperature range of calibration, it predicts that melts remain carbonatitic at any depth below cratons. Our conclusions conflict with the hypothesis of Russell et al. (2012) for cratons. However, we recognize that, more silicic melts could be produced with a hotter geotherm and this could match Russell's model. The temperature range required to stabilize orthopyroxeneundersaturated melts nevertheless needs an investigation using our model in the pressuretemperature space, which is beyond the scope of our study.

\section{Conclusion}

We developed a model calculating the silica activity of the $\mathrm{CO}_{2}-\mathrm{H}_{2} \mathrm{O}$-bearing melts typically produced by partial melting of the $\mathrm{H}_{2} \mathrm{O}$-bearing carbonated mantle. It is calibrated and reproduces a large experimental database (491 melts), covering an important chemical diversity and large pressure-temperature ranges $\left(1-10 \mathrm{GPa}, 1100-1700^{\circ} \mathrm{C}\right)$. Our model is therefore applicable to most of upper mantle conditions without extrapolation. The water content and the $\mathrm{Ca} / \mathrm{Mg}$ ratio (correlated to pressure) are found to be among the most influent parameters on the $\mathrm{a}_{\mathrm{SiO}_{2}(\mathrm{l})}-\mathrm{X}_{\mathrm{SiO}_{2}(\mathrm{l})}$ relationships in carbonate melts.

Our model can be used to characterize the change of the melt composition along ridge adiabatic pressure-temperature paths. In contrast to the gradual transition predicted by ideal mixing and the model of Dasgupta et al. (2013), we show that carbonatitic melts with a maximum $\mathrm{SiO}_{2}$ content of $\sim 10 \mathrm{wt} . \%$ can be stabilized at the onset of incipient melting by "redox melting" at depth of $150 \mathrm{~km}$. Furthermore, the liquid is predicted to change abruptly from a carbonatitic to a carbonated silicate melt $\left(\mathrm{SiO}_{2}\right.$ content $\left.\sim 25 \mathrm{wt} . \%\right)$ above $\sim 110-75 \mathrm{~km}$ depth respectively, with potential immiscibility between a carbonate-rich and a silicate-rich melt in this range. The extrapolation of our model to cratonic mantle lithosphere conditions 
predicts the stabilization of carbonatitic melts, with no increase of the $\mathrm{SiO}_{2}$ content during the ascent conversely to the model of Russell et al. (2012).

\section{Acknowledgements}

This work, part of the ElectroLith project, benefited from funding by the European Research Council (ERC project \#279790) and the French agency for research (ANR project \#2010 BLAN62101). The authors would like to thank Klaus Mezger and Carmen Sanchez-Valle for careful and efficient editorial handling as well as two anonymous reviewers for their constructive comments that significantly improved the manuscript. We also acknowledge Ida Di Carlo (Institut des Sciences de la Terre d'Orléans, Orléans), Jean-Marc Hénot and JeanLuc Devidal (Laboratoire Magmas et Volcans, Clermont-Ferrand) for analytical support. 
Transition Carbonate-silicate mantle melt model Massuyeau et al. 2015

\section{Figures}

Table 1:

\begin{tabular}{|c|c|c|c|c|c|}
\hline Study & Temperature $\left({ }^{\circ} \mathbf{C}\right)$ & Pressure (Gpa) & System & Equilibrium & $\begin{array}{l}\text { Number of } \\
\text { experiments }\end{array}$ \\
\hline Wasylenki et al. 2003 & $1270-1390$ & 1 & NKFTCrMnCMAS & $C L$ & 17 \\
\hline Hirose and Kushiro 1993 & $1250-1500$ & $1-3$ & NKFTCrMnCMAS & $C L$ & 26 \\
\hline Gaetani and Grove 1998 & $1185-1370$ & $1.2-2$ & NKFTPCrMnCMAS- $\mathrm{H}_{2} \mathrm{O}$ & $C L$ & 19 \\
\hline Hirose and Kawamoto 1995 & $1100-1350$ & 1 & 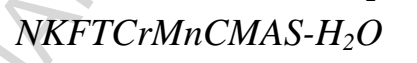 & $C L$ & 8 \\
\hline Dalton and Presnall 1998a & $1405-1505$ & 6 & $\mathrm{CMAS}-\mathrm{CO}_{2}$ & $\mathrm{CL}$ & 5 \\
\hline Dalton and Presnall 1998b & $1245-1430$ & $3-7$ & CMAS- $\mathrm{CO}_{2}$ & $\mathrm{CL}$ & 6 \\
\hline Gudfinnsson and Presnall 2005 & $1400-1800$ & $3.2-8$ & CMAS- $\mathrm{CO}_{2}$ & $\mathrm{CL}$ & 22 \\
\hline Keshav et al. 2011 & $1525-1675$ & $10-14$ & CMAS- $\mathrm{CO}_{2}$ & $\mathrm{CL}$ & 5 \\
\hline Keshav and Gudfinnsson 2013 & $1330-1390$ & $1.1-1.7$ & $\mathrm{CMAS}-\mathrm{CO}_{2}$ & $\mathrm{CL}$ & 3 \\
\hline Novella et al. 2014 & $1225-1560$ & $2.1-3$ & $\mathrm{CMAS}-\mathrm{CO}_{2}$ & $\mathrm{CL}$ & 19 \\
\hline Ryabchikov et al. 1989 & $1400-1450$ & 5 & $\mathrm{NKFCMAS-C \textrm {O } _ { 2 }}$ & $C L$ & 3 \\
\hline Ghosh et al. 2009 & $1550-1560$ & $12.5-13.5$ & $\mathrm{NKFTCrCMAS- \textrm {CO } _ { 2 }}$ & $C L$ & 2 \\
\hline Ghosh et al. 2014 & $1600-1700$ & $10-12.5$ & $\mathrm{NKFTCrCMAS-C \textrm {O } _ { 2 }}$ & $C L$ & 3 \\
\hline Dasgupta et al. 2007 & $1300-1600$ & 3 & $\mathrm{NKFTCrMnCMAS- \textrm {CO } _ { 2 }}$ & $C L$ & 19 \\
\hline $\begin{array}{l}\text { Dasgupta and Hirschmann } \\
2007 a\end{array}$ & $1200-1260$ & 6.6 & $\mathrm{NKFTCrMnCMAS-CO}$ & $C L$ & 29 \\
\hline Dasgupta and Hirschmann & $1330-1360$ & 6.6 & 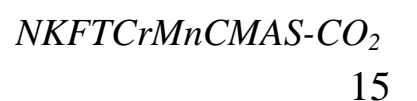 & $C L$ & 2 \\
\hline
\end{tabular}


Transition Carbonate-silicate mantle melt model Massuyeau et al. 2015

$2007 b$

Dasgupta et al. 2013

Rohrbach and Schmidt 2011

Mallik and Dasgupta 2013

Mallik and Dasgupta 2014

Tenner et al. 2012

Brey et al. 2008

Brey et al. 2011

Foley et al. 2009

Thibault et al. 1992

Girnis et al. 2011

Brey et al. 2009

Brooker and Kjarsgaard 2011

Lee and Wyllie 1996

Brooker and Hamilton 1990

Massuyeau et al. (this study)

Martin et al. 2012

Martin et al. 2013

Dasgupta et al. 2006

Brooker 1998

$\begin{array}{ll}1300-1750 & 2-5 \\ 1575 & 10 \\ 1375 & 3 \\ 1375 & 3 \\ 1200-1450 & 3.5 \\ 1300-1700 & 6-10 \\ 1200-1700 & 6-10 \\ 1090-1290 & 4-6 \\ 1100 & 3 \\ 1400-1800 & 6-10 \\ 1300-1600 & 6-10 \\ 1275-1700 & 1-2.5 \\ 1350-1450 & 2.5 \\ 1225 & 1.5 \\ 1300-1400 & 3 \\ 1220 & 1.7 \\ 1160-1260 & 1-3.2 \\ 1225-1375 & 3 \\ 1250-1300 & 2.5\end{array}$

$\mathrm{NKFTCrMnCMAS-CO}$ $\mathrm{NKFTCrCMAS-CO}(\mathrm{Ni})$

$\mathrm{NKFTCrMnCMAS-CO}$

NKFTCrMnCMAS-CO

NKFTCrMnCMAS- $\mathrm{CO}_{2}, \mathrm{H}_{2} \mathrm{O}$

$\mathrm{NKFTPCrMnCMAS-CO}(\mathrm{Ni})$

$\mathrm{NKFTPCrMnCMAS-CO}(\mathrm{Ni})$

$\mathrm{NKFTCrCMAS}-\mathrm{CO}_{2}, \mathrm{H}_{2} \mathrm{O}$

$\mathrm{NKFTMnCMAS}-\mathrm{CO}_{2}, \mathrm{H}_{2} \mathrm{O}$

$\mathrm{NKFTPCrCMAS}-\mathrm{CO}_{2}, \mathrm{H}_{2} \mathrm{O}(\mathrm{Ni})$

$\mathrm{NKFTPCrMnCMAS}-\mathrm{CO}_{2}, \mathrm{H}_{2} \mathrm{O}(\mathrm{Ni})$

$\mathrm{NCAS}-\mathrm{CO}_{2}$

NCMAS-CO2

NKCMAS-CO2

NKFCMAS-CO2

NKFTPCMAS-CO

$\mathrm{NKFTPCMAS-C \textrm {O } _ { 2 }}$

$\mathrm{NKFTCrMnCMAS-CO}$

$\mathrm{NKFTPCrMnCMAS-CO}, \mathrm{F}$

$\begin{array}{ll}C L & 7 \\ C L & 1 \\ C L & 6 \\ C L & 8 \\ C L & 16 \\ C L & 22 \\ C L & 15 \\ C L & 12 \\ C L & 1 \\ C L & 11 \\ C L & 6 \\ \mathrm{LL} & 29 \\ L L & 7 \\ L L & 7 \\ L L & 8 \\ L L & 7 \\ L L & 12 \\ L L & 5 \\ L L & 16\end{array}$

TOTAL

491

Experimental database used in this study. The experiments labelled in italics referred to the systems considered as 'quasi-natural' in the text.

$\mathrm{A}: \mathrm{Al}_{2} \mathrm{O}_{3}, \mathrm{C}: \mathrm{CaO}, \mathrm{Cr}: \mathrm{Cr}_{2} \mathrm{O}_{3}, \mathrm{~F}: \mathrm{Feo}, \mathrm{Ir}: \mathrm{IrO}_{2}, \mathrm{~K}: \mathrm{K}_{2} \mathrm{O}, \mathrm{M}: \mathrm{MgO}, \mathrm{Mn}: \mathrm{MnO}, \mathrm{N}: \mathrm{Na}_{2} \mathrm{O}, \mathrm{Ni}: \mathrm{NiO}, \mathrm{P}: \mathrm{P}_{2} \mathrm{O}_{5}, \mathrm{~S}: \mathrm{SiO}$, T: TiO 
Table 2:

\begin{tabular}{|c|c|}
\hline Parameter & Calc. Value (J.mol $\left.{ }^{-1}\right)$ \\
\hline $\mathrm{W}^{\mathrm{a}} \mathrm{SiO}_{2}-\mathrm{CO}_{2}$ & $-222792 \pm 13193$ \\
\hline $\mathrm{W}^{\mathrm{b}} \mathrm{SiO}_{2}-\mathrm{CO}_{2}$ & $20238 \pm 7901$ \\
\hline $\mathrm{WAl}_{2} \mathrm{O}_{3}-\mathrm{SiO}_{2}$ & $-86189 \pm 24503$ \\
\hline${\mathrm{WCaO}-\mathrm{SiO}_{2}}_{2}$ & $83743 \pm 5065$ \\
\hline $\mathrm{WNa}_{2} \mathrm{O}-\mathrm{SiO}_{2}$ & $-85227 \pm 33274$ \\
\hline $\mathrm{WK}_{2} \mathrm{O}-\mathrm{SiO}_{2}$ & $-85967 \pm 41414$ \\
\hline $\mathrm{WAl}_{2} \mathrm{O}_{3}-\mathrm{CO}_{2}$ & $-791128 \pm 91536$ \\
\hline $\mathrm{WFeO}-\mathrm{CO}_{2}$ & $-428390 \pm 48413$ \\
\hline $\mathrm{WMgO}_{\mathrm{MgO}}$ & $-91257 \pm 10254$ \\
\hline $\mathrm{WNa}_{2} \mathrm{O}-\mathrm{CO}_{2}$ & $-266442 \pm 48438$ \\
\hline $\mathrm{WK}_{2} \mathrm{O}-\mathrm{CO}_{2}$ & $-277798 \pm 84106$ \\
\hline $\mathrm{WH}_{2} \mathrm{O}-\mathrm{CO}_{2}$ & $-38029 \pm 15844$ \\
\hline $\mathrm{WAl}_{2} \mathrm{O}_{3}-\mathrm{FeO}$ & $-990442 \pm 158670$ \\
\hline $\mathrm{WAl}_{2} \mathrm{O}_{3}-\mathrm{MgO}$ & $174780 \pm 62096$ \\
\hline WFeO-CaO & $722813 \pm 106230$ \\
\hline WCaO-Na ${ }_{2} \mathrm{O}$ & $-168280 \pm 41555$ \\
\hline
\end{tabular}

Optimized Margules parameters for the calculation of the silica activity coefficient $\left(\gamma_{\mathrm{SiO}_{2}(\mathrm{l})}\right)$

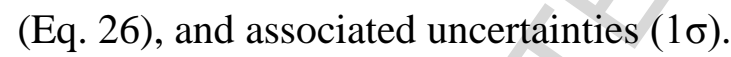

\section{Figure 1:}

P-T conditions of the experimental database used in this study, with solidus temperatures for different bulk compositions. The experimental data points correspond to 1) liquid-olivineorthopyroxene equilibrium, and 2) immiscible carbonate-rich and silicate-rich liquids equilibrium. Solidus temperatures are from Wallace and Green (1988; "W.\&G.1988”), Dalton and Presnall (1998a; “D.\&P.1998”), Hirschmann (2000; "H.2000”), Brey et al. (2009; "B.2009”), Foley et al. (2009; "F.2009”), Brey et al. (2011; “B.2011”), Dasgupta (2013; "D.2013”), Keshav et al. (2011; "K.2011”), Keshav and Gudfinnsson (2013; "K.\&G.2013"). The CMS- $\mathrm{CO}_{2}$ solidus is calculated from the combination of the solidus temperatures of Dalton and Presnall (1998a), from 0 to $7 \mathrm{GPa}$, and Keshav et al. (2011) at higher pressures. The CMAS- $\mathrm{CO}_{2}$ solidus is calculated from the combination of the solidus temperatures of Keshav and Gudfinnsson (2013), from 0 to $6.5 \mathrm{GPa}$, and Keshav et al. (2011) at higher pressures.

\section{Figure 2:}

(A-E, G) Silica activity as a function of silica content in experimental partial melts coexisting with olivine and orthopyroxene. (A) and (B) represent the experimental data in dry systems only, as a function of pressure and temperature respectively. (C) Comparison between nominally dry and hydrated experimental melts (all the experimental data are represented 
here). (D) Comparison between simple (CMS and CMAS) and dry quasi-natural systems. (E,G) Experimental data in dry systems sorted as a function of different oxide molar ratios: $\mathrm{Ca} / \mathrm{Mg}(\mathrm{E})$ and $(\mathrm{Na}+\mathrm{K}) / \mathrm{Mg}(\mathrm{G})$.

(F) Evolution of the $\mathrm{Ca} / \mathrm{Mg}$ molar ratio as a function of the pressure for the experimental melts coexisting with olivine and orthopyroxene. The black solid line represent the fit of the data with $<20$ wt. $\% \mathrm{SiO}_{2}\left(\mathrm{Ca} / \mathrm{Mg}=5 *\left(\mathrm{e}^{(-1.5 * \mathrm{P})}\right)^{0.3}+0.4\right)$.

(H) Activity ratios between carbonate-rich (CL) and silicate-rich (SL) liquids measured in immiscibility experiments $\left(\mathrm{RT} \ln \left(\gamma_{\mathrm{SiO}_{2}(\mathrm{l})}^{\mathrm{CL}} / \gamma_{\mathrm{SiO}_{2}(\mathrm{l})}^{\mathrm{SL}}\right)=\mathrm{RT} \ln \left(\mathrm{X}_{\mathrm{SiO}_{2}(\mathrm{l})}^{\mathrm{SL}} / \mathrm{X}_{\mathrm{SiO}_{2}(\mathrm{l})}^{\mathrm{CL}}\right)\right)$ as a function of silica content, and sorted for different $(\mathrm{Na}+\mathrm{K}) / \mathrm{Mg}$ ratio in the silicate liquid. The grey dashed line separates carbonate liquids from silicate liquids.

\section{Figure 3:}

(A) Comparison of the $\mathrm{SiO}_{2}$ melt molar fraction calculated with our model to that measured in experimental melts coexisting with olivine and orthopyroxene. (B) Comparison of $\mathrm{RT} \ln \left(\gamma_{\mathrm{SiO}_{2}}^{\mathrm{CL}} / \gamma_{\mathrm{SiO}_{2}}^{\mathrm{SL}}\right)$ calculated with our model to that measured in immiscibility experiments (i.e., $\mathrm{RT} \ln \left(\mathrm{X}_{\mathrm{SiO}_{2}}^{\mathrm{SL}} / \mathrm{X}_{\mathrm{SiO}_{2}}^{\mathrm{CL}}\right)$ ). The uncertainties on $\mathrm{X}_{\mathrm{SiO}_{2}(1)}$ and $\mathrm{RT} \ln \left(\mathrm{X}_{\mathrm{SiO}_{2}}^{\mathrm{CL}} / \mathrm{X}_{\mathrm{SiO}_{2}}^{\mathrm{SL}}\right)$ are reported as given from the experimental studies or, when unspecified, approximated by typical errors (see Supplementary Information Part 4b).

\section{Figure 4:}

Predicted evolution of silica activity as a function of $\mathrm{X}_{\mathrm{SiO}_{2}(\mathrm{l})}$ according to our model for various melt chemical compositions between carbonate end-members and silicate endmembers. The molar composition of the carbonate is mentioned in the legend (see Table S5 and Supplementary Information Part 6 for composition and calculation details). (A) Evolution of the silica activity as a function of $\mathrm{Ca} / \mathrm{Mg}$ ratio and water content in the carbonate melt at $1400^{\circ} \mathrm{C}$ (except for the light blue curve at $1600^{\circ} \mathrm{C}$ ). The silicate end-member is a basaltic component, except for the pink dashed curve, representing the silica activity calculated with a basanitic component (see Table S5). (B) Evolution of the silica activity as a function of the $(\mathrm{Na}+\mathrm{K}) / \mathrm{Mg}$ ratio at $1400^{\circ} \mathrm{C}$. The silicate end-member is a basaltic component (see Table S5). (C) Evolution of the silica activity as predicted by the model of Dasgupta et al. (2013) compared to that of our model using identical carbonate and silicate end-members (see Table S5).

\section{Figure 5 :}

Evolution of melt silica content in (A-B) oceanic and (C) cratonic settings according to our model (see Table S5 and Supplementary Information Part 6 for composition and calculation details). (A) Melt evolution of dry (brown curve) and hydrous $\left(\mathrm{H}_{2} \mathrm{O} / \mathrm{CO}_{2}=0.1,0.2\right.$ and 0.5; blue curves) systems along a ridge adiabat with potential temperature $\mathrm{Tp}=1350^{\circ} \mathrm{C}$, compared to ideal mixing (grey dashed curve) and the model of Dasgupta et al. (2013) (purple curve, 
dashed for extrapolation). The shaded regions for dry (light brown) and hydrous (blue) systems represent the regions where melt composition cannot be unequivocally predicted and where immiscibility may occur. Example of uncertainties on predicted silica content is reported as light green shaded area for the dry system (see Supplementary Information Part 4c). (B) Melt evolution of hydrous system $\left(\mathrm{H}_{2} \mathrm{O} / \mathrm{CO}_{2}=0.2\right)$ for different potential temperatures $\left(1250^{\circ} \mathrm{C}, 1350^{\circ} \mathrm{C}\right.$ and $\left.1450^{\circ} \mathrm{C}\right)$. (C) Melt evolution of dry (brown curve) and hydrous (blue curves) systems along a cratonic geotherm (Fig. S7), compared to the model of Russell et al. (2012) (purple curve). 


\section{References}

Asimow, P.D., Dixon, J.E., Langmuir, C.H., 2004. A hydrous melting and fractionation model for mid-ocean ridge basalts: Application to the Mid-Atlantic Ridge near the Azores. Geochemistry Geophysics Geosystems, 5, doi: 10.1029/2003GC000568.

Asimow, P.D., Langmuir, C.H., 2003. The importance of water to oceanic mantle melting regimes. Nature, $421,815-820$.

Barker, D., 2001. Calculated silica activities in carbonatite liquids. Contributions to Mineralogy and Petrology, 141, 704-709.

Berman, R.G., Brown, T.H., 1984. A thermodynamic model for multicomponent melts, with application to the system $\mathrm{CaO}-\mathrm{Al}_{2} \mathrm{O}_{3}-\mathrm{SiO}_{2}$. Geochimica et Cosmochimica Acta, 48, 661-678.

Brey, G.P., Green, D.H., 1976. Solubility of $\mathrm{CO}_{2}$ in olivine melilitite at high pressures and role of $\mathrm{CO}_{2}$ in the Earth's upper mantle. Contributions to Mineralogy and Petrology, $55,217-230$

Brey, G.P., Brice, W.R., Ellis, D.J., Green, D.H., Harris, K.L., Ryabchikov, I.D., 1983. Pyroxene-carbonate reactions in the upper mantle. Earth and Planetary Science Letters, 62, 63-74.

Brey, G.P., Bulatov, V.K., Girnis, A.V., 2009. Influence of water and fluorine on melting of carbonated peridotite at 6 and $10 \mathrm{GPa}$. Lithos, 112S, 249-259.

Brey, G.P., Bulatov, V.K., Girnis, A.V., 2011. Melting of K-rich carbonated peridotite at 6$10 \mathrm{GPa}$ and the stability of K-phases in the upper mantle. Chemical Geology, 281, 333-342.

Brey, G.P., Bulatov, V.K., Girnis, A.V., Lahaye, Y., 2008. Experimental Melting of Carbonated Peridotite at 6-10 GPa. Journal of Petrology, 49, 797-821.

Brooker, R.A., 1998. The Effect of $\mathrm{CO}_{2}$ Saturation on Immiscibility between Silicate and Carbonate Liquids: an Experimental Study. Journal of Petrology, 39, 1905-1915.

Brooker, R.A., Hamilton, D.L., 1990. Three-liquid immiscibility and the origin of carbonatites. Nature, 346, 459-462.

Brooker, R.A., Kjarsgaard, B.A., 2011. Silicate-Carbonate Liquid Immiscibility and Phase Relations in the System $\mathrm{SiO}_{2}-\mathrm{Na}_{2} \mathrm{O}-\mathrm{Al}_{2} \mathrm{O}_{3}-\mathrm{CaO}-\mathrm{CO}_{2}$ at $0.1-2.5 \mathrm{GPa}$ with Applications to Carbonatite Genesis. Journal of Petrology, 52, 1281-1305.

Carmichael, I.S.E., Nicholls, J., Smith, A.L., 1970. Silica activity in igneous rocks. American Mineralogist, 55, 246-263. 
Dalton, J.A., Presnall, D.C., 1998a. Carbonatitic melts along the solidus of model lherzolite in the system $\mathrm{CaO}-\mathrm{MgO}-\mathrm{Al}_{2} \mathrm{O}_{3}-\mathrm{SiO}_{2}-\mathrm{CO}_{2}$ from 3 to $7 \mathrm{GPa}$. Contributions to Mineralogy and Petrology, 131, 123-135.

Dalton, J.A., Presnall, D.C., 1998b. The Continuum of Primary Carbonatitic-Kimberlitic Melt Compositions in Equilibrium with Lherzolite: Data from the System $\mathrm{CaO}-\mathrm{MgO}-$ $\mathrm{Al}_{2} \mathrm{O}_{3}-\mathrm{SiO}_{2}-\mathrm{CO}_{2}$ at $6 \mathrm{GPa}$. Journal of Petrology, 39, 1953-1964.

Dalton, J.A., Wood, B.J., 1993. The compositions of primary carbonate melts and their evolution through wallrock reaction in the mantle. Earth and Planetary Science Letters, 119, 511-525.

Dasgupta, R., Hirschmann, M.M., 2006. Melting in the Earth's deep upper mantle caused by carbon dioxide. Natures, 440, 659-662

Dasgupta, R., Hirschmann, M.M., 2007a. A modified iterative sandwich method for determination of near-solidus partial melt compositions. II. Application to determination of near-solidus melt compositions of carbonated peridotite. Contributions to Mineralogy and Petrology, 154, 647-661.

Dasgupta, R., Hirschmann, M.M., 2007b. Effect of variable carbonate concentration on the solidus of mantle peridotite. American Mineralogist, 92, 370-379.

Dasgupta, R., Hirschmann, M.M., 2010. The deep carbon cycle and melting in Earth's interior. Earth and Planetary Science Letters, 298, 1-13.

Dasgupta, R., Hirschmann, M.M., Dellas, N., 2005. The effect of bulk composition on the solidus of carbonated eclogite from partial melting experiments at $3 \mathrm{GPa}$. Contributions to Mineralogy and Petrology, 149, 288-305.

Dasgupta, R., Hirschmann, M.M., Smith, N.D., 2007. Partial Melting Experiments of Peridotite $+\mathrm{CO}_{2}$ at $3 \mathrm{GPa}$ and Genesis of Alkalic Ocean Island Basalts. Journal of Petrology, 48, 2093-2124.

Dasgupta, R., Hirschmann, M.M., Stalker, K., 2006. Immiscible Transition from Carbonaterich to Silicate-rich Melts in the $3 \mathrm{GPa}$ Melting Interval of Eclogite $+\mathrm{CO} 2$ and Genesis of Silica-undersaturated Ocean Island Lavas. Journal of Petrology, 47, 647671.

Dasgupta, R., 2013. Ingassing, Storage, and Outgassing of Terrestrial Carbon through Geologic Time. Reviews in Mineralogy and Geochemistry, 75, 183-229.

Dasgupta, R., Mallik, A., Tsuno, K., Withers, A.C., Hirth, G., Hirschmann, M.M., 2013. Carbon-dioxide-rich silicate melt in the Earth's upper mantle. Nature, 493, 211-215. 
DeCapitani, C., Kirschen, M., 1998. A generalized multicomponent excess function with application to immiscible liquids in the system $\mathrm{CaO}-\mathrm{SiO}_{2}-\mathrm{TiO}_{2}$. Geochimica et Cosmochimica Acta, 62, 3753-3763.

Foley, S.F., Yaxley, G.M., Rosenthal, A., Buhre, S., Kiseeva, E.S., Rapp, R.P., Jacob, D.E., 2009. The composition of near-solidus melts of peridotite in the presence of $\mathrm{CO}_{2}$ and $\mathrm{H}_{2} \mathrm{O}$ between 40 and 60 kbar. Lithos, 112S: 274-283.

Gaetani, G.A., Grove, T.L., 1998. The influence of water on melting of mantle peridotite. Contributions to Mineralogy and Petrology, 131, 323-346.

Gaillard, F., Malki, M., Iacono-Marziano, G., Pichavant, M., Scaillet, B., 2008. Carbonatite melts and Electrical Conductivity in the Asthenosphere. Science, 322, 1363-1365.

Ghiorso, M.S., Carmichael, I.S.E., 1980. A Regular Solution Model for Met-Aluminous Silicate Liquids: Applications to Geothermometry, Immiscibility, and the Source Regions of Basic Magmas. Contributions to Mineralogy and Petrology, 71, 323-342.

Ghiorso, M.S., Carmichael, I.S.E., Rivers, M.L., Sack, R.O., 1983. The Gibbs free energy of mixing of natural silicate liquids; an expanded regular solution approximation for the calculation of magmatic intensive variables. Contributions to Mineralogy and Petrology, 84, 107-145.

Ghiorso, M.S., Hirschmann, M.M., Reiners, P.W., Kress, V.C., 2002. The pMELTS: A revision of MELTS for improved calculation of phase relations and major element partitioning related to partial melting of the mantle to $3 \mathrm{GPa}$. Geochemistry Geophysics Geosystems, 3, doi: 10.1029/2001GC000217.

Ghiorso, M.S., Sack, R.O., 1995. Chemical mass transfer in magmatic processes IV. A revised and internally consistent thermodynamic model for the interpolation and extrapolation of liquid-solid equilibria in magmatic systems at elevated temperatures and pressures. Contributions to Mineralogy and Petrology, 119, 197-212.

Ghosh, S., Ohtani, E., Litasov, K.D., Terasaki, H., 2009. Solidus of carbonated peridotite from 10 to $20 \mathrm{GPa}$ and origin of magnesiocarbonatite melt in the Earth's deep mantle. Chemical Geology, 262, 17-28.

Ghosh, S., Litasov, K., Ohtani, E., 2014. Phase relations and melting of carbonated peridotite between 10 and $20 \mathrm{GPa}$ : a proxy for alkali- and $\mathrm{CO}_{2}$-rich silicate melts in the deep mantle. Contributions to Mineralogy and Petrology, 167, 23p.

Girnis, A.V., Bulatov, V.K., Brey, G.P., 2011. Formation of primary kimberlite melts Constraints from experiments at 6-12 $\mathrm{GPa}$ and variable $\mathrm{CO}_{2} / \mathrm{H}_{2} \mathrm{O}$. Lithos, 127, 401413. 
Green, D.H., Liebermann, R.C., 1976. Phase-equilibria and elastic properties of a pyrolite model for oceanic upper mantle. Tectonophysics, 32, 61-92.

Green, D.H., Falloon, T.J., 1998. Pyrolite: A Ringwood concept and its current expression. In: Jackson, I., editor. The Earth's Mantle: Composition, Structure and Evolution. New York: Cambridge University Press, 566 pp.

Green, E.C.R., Holland, T.J.B., Powell, R., 2012a. A thermodynamic model for silicate melt in $\mathrm{CaO}-\mathrm{MgO}-\mathrm{Al}_{2} \mathrm{O}_{3}-\mathrm{SiO}_{2}$ to $50 \mathrm{kbar}$ and $1800^{\circ} \mathrm{C}$. Journal of Metamorphic Geology, 30, 579-597.

Green, E.C.R., Holland, T.J.B., Powell, R., White, R.W., 2012b. Garnet and spinel lherzolite assemblages in $\mathrm{MgO}-\mathrm{Al}_{2} \mathrm{O}_{3}-\mathrm{SiO}_{2}$ and $\mathrm{CaO}-\mathrm{MgO}-\mathrm{Al}_{2} \mathrm{O}_{3}-\mathrm{SiO}_{2}$ : thermodynamic models and an experimental conflict. Journal of Metamorphic Geology, 30, 561-577.

Gudfinnsson, G.H., Presnall, D.C., 2005. Continuous Gradations among Primary Carbonatitic, Kimberlitic, Melilititic, Basaltic, Picritic, and Komatiitic Melts in Equilibrium with Garnet Lherzolite at 3-8 GPa. Journal of Petrology, 46, 1645-1659.

Guillot, B., Sator, N., 2011. Carbon dioxide in silicate melts: A molecular dynamics simulation study. Geochimica et Cosmochimica Acta, 75, 1829-1857.

Hammouda, T., 2003. High-pressure melting of carbonated eclogite and experimental constraints on carbon recycling and storage in the mantle. Earth and Planetary Science Letters, 214, 357-368.

Hammouda, T., Keshav, S., 2015. Melting in the mantle in presence of carbon; review of experiments and discussion on the origin of carbonatites. Chemical Geology, in press.

Hirose, K., Kawamoto, T., 1995. Hydrous partial melting of lherzolite at 1 GPa: The effect of $\mathrm{H}_{2} \mathrm{O}$ on the genesis of basaltic magmas. Earth and Planetary Science Letters, 133, 463-473.

Hirose, K., Kushiro, I., 1993. Partial melting of dry peridotites at high pressures: Determination of compositions of melts segregated from peridotite using aggregates of diamond. Earth and Planetary Science Letters, 114, 477-489.

Hirschmann, M.M., 1991. Thermodynamics of multicomponent olivines and the solution properties of $(\mathrm{Ni}, \mathrm{Mg}, \mathrm{Fe})_{2} \mathrm{SiO}_{4}$ and $(\mathrm{Ca}, \mathrm{Mg}, \mathrm{Fe})_{2} \mathrm{SiO}_{4}$ olivines.American Mineralogist, $76,1232-1248$.

Hirschmann, M.M., 2000. Mantle solidus: Experimental constraints and the effects of peridotite composition. Geochemistry Geophysics Geosystems, 1, doi: 10.1029/2000GC000070.

Hirschmann, M.M., 2010. Partial melt in the oceanic low velocity zone. Physics of the Earth and Planetary Interiors, 179, 60-71. 
Hirschmann, M.M., Baker, M.B., Stolper, E.M., 1998. The Effect of Alkalis on the Silica Content of Mantle-Derived Melts. Geochimica et Cosmochimica Acta, 62, 883-902.

Hirschmann, M.M., Tenner, T., Aubaud, C., Withers, A.C., 2009. Dehydration melting of nominally anhydrous mantle: The primacy of partitioning. Physics of the Earth and Planetary Interiors, 176, 54-68.

Holland, T.J.B., Powell, R., 2011. An improved and extended internally consistent thermodynamic dataset for phases of petrological interest, involving a new equation of state for solids. Journal of Metamorphic Geology, 29, 333-383.

Holtzman, B.K., Kohlstedt, D.L., 2007. Stress-driven Melt Segregation and Strain Partitioning in Partially Molten Rocks: Effects of Stress and Strain. Journal of Petrology, 48, 2379-2406.

Jakobsson, S., Holloway, J.R., 2008. Mantle melting in equilibrium with an Iron-WüstiteGraphite buffered COH-fluid. Contributions to Mineralogy and Petrology, 155, 247256.

Jones, A.P., Genge, M., Carmody, L., 2013. Carbonate Melts and Carbonatites. Reviews in Mineralogy and Geochemistry, 75, 289-322.

Katz, R.F., Spiegelman, M., Langmuir, C.H., 2003. A new parameterization of hydrous mantle melting. Geochemistry Geophysics Geosystems, 4, 1073, doi:10.1029/2002GC000433.

Keshav, S., Gudfinnsson, G.H., 2013. Silicate liquid-carbonatite liquid transition along the melting curve of model, vapor-saturated peridotite in the system $\mathrm{CaO}-\mathrm{MgO}-\mathrm{Al}_{2} \mathrm{O}_{3}$ $\mathrm{SiO}_{2}-\mathrm{CO}_{2}$ from 1.1 to $2 \mathrm{GPa}$. Journal of Geophysical Research: Solid Earth, 118, 3341-3353.

Keshav, S., Gudfinnsson, G.H., Presnall, D.C., 2011. Melting Phase Relations of Simplified Carbonated Peridotite at $12-26 \mathrm{GPa}$ in the Systems $\mathrm{CaO}-\mathrm{MgO}-\mathrm{SiO}_{2}-\mathrm{CO}_{2}$ and $\mathrm{CaO}-$ $\mathrm{MgO}-\mathrm{Al}_{2} \mathrm{O}_{3}-\mathrm{SiO}_{2}-\mathrm{CO}_{2}$ : Highly Calcic Magmas in the Transition Zone of the Earth. Journal of Petrology, 52, 2265-2291.

Kiseeva, E.S. et al., 2012. An Experimental Study of Carbonated Eclogite at 3.5-5.5 GPaImplications for Silicate and Carbonate Metasomatism in the Cratonic Mantle. Journal of Petrology, 53, 727-759.

Kogiso, T., Hirschmann, M.M., Pertermann, M., 2004. High-pressure Partial Melting of Mafic Lithologies in the Mantle. Journal of Petrology, 45, 2407-2422.

Lee, W.-J., Wyllie, P.J., 1996. Liquid Immiscibility in the Join $\mathrm{NaAlSi}_{3} \mathrm{O}_{8}-\mathrm{CaCO}_{3}$ to $2.5 \mathrm{GPa}$ and the Origin of Calciocarbonatite Magmas. Journal of Petrology, 37, 1125-1152. 
Lee, C.-T.A., Luffi, P., Chin, E.J., 2011. Building and destroying continental mantle. Annual Reviews of Earth and Planetary Sciences, 39, 59-90.

Litasov, K., Ohtani, E., 2010. The solidus of carbonated eclogite in the system $\mathrm{CaO}-\mathrm{Al}_{2} \mathrm{O}_{3}-$ $\mathrm{MgO}-\mathrm{SiO}_{2}-\mathrm{Na}_{2} \mathrm{O}-\mathrm{CO}_{2}$ to $32 \mathrm{GPa}$ and carbonatite liquid in the deep mantle. Earth and Planetary Science Letters, 295, 115-126.

Litasov, K.D., Ohtani, E., 2009. Solidus and phase relations of carbonated peridotite in the system $\mathrm{CaO}-\mathrm{Al} 2 \mathrm{O} 3-\mathrm{MgO}-\mathrm{SiO} 2-\mathrm{Na} 2 \mathrm{O}-\mathrm{CO} 2$ to the lower mantle depths. Physics of the Earth and Planetary Interiors, 177, 46-58.

Liu, X.I., O'Neill, H.S.C., Berry, A.J., 2006. The Effects of Small Amounts of $\mathrm{H}_{2} \mathrm{O}, \mathrm{CO}_{2}$ and $\mathrm{Na} 2 \mathrm{O}$ on the Partial Melting of Spinel Lherzolite in the System $\mathrm{CaO}-\mathrm{MgO}-\mathrm{Al}_{2} \mathrm{O}_{3}-$ $\mathrm{SiO}_{2} \pm \mathrm{H}_{2} \mathrm{O} \pm \mathrm{CO}_{2} \pm \mathrm{Na}_{2} \mathrm{O}$ at $1.1 \mathrm{GPa}$. Journal of Petrology, 47, 409-434.

Luth, R.W., 2009. The activity of silica in kimberlites, revisited. Contributions to Mineralogy and Petrology, 158, 283-294.

Mallik, A., Dasgupta, R., 2013. Reactive Infiltration of MORB-Eclogite-Derived Carbonated Silicate Melt into Fertile Peridotite at $3 \mathrm{GPa}$ and Genesis of Alkalic Magmas. Journal of Petrology, 54, 2267-2300.

Mallik, A., Dasgupta, R., 2014. Effect of variable $\mathrm{CO}_{2}$ on eclogite-derived andesite and lherzolite reaction at $3 \mathrm{GPa}$-Implications for mantle source characteristics of alkalic ocean island basalts. Geochemistry Geophysics Geosystems, 15, 1533-1557.

Martin, L.H.J., Schmidt, M.W., Mattsson, H.B., Ulmer, P., Hametner, K., Günther, D., 2012. Element partitioning between immiscible carbonatite-kamafugite melts with application to the Italian ultrapotassic suite. Chemical Geology, 320-321, 96-112.

Martin, L.H.J., Schmidt, M.W., Mattsson, H.B., Günther, D., 2013. Element partitioning between Immiscible Carbonatite and Silicate Melts for Dry and $\mathrm{H}_{2} \mathrm{O}$-bearing Systems at 1-3 GPa. Journal of Petrology, 54, 2301-2338.

Morizet Y., Brooker R.A., Kohn, S.C., 2002. CO2 in haplo-phonolitic melt: solubility, speciation and carbonate complexation, Geochimica et Cosmochimica Acta, 66, 1809-1820.

Moore, K.R., Wood, B.J., 1998. The Transition from Carbonate to Silicate Melts in the $\mathrm{CaO}-\mathrm{MgO}-\mathrm{SiO} 2-\mathrm{CO} 2$ System. Journal of Petrology, 39, 1943-1951.

Moore, K.R., 2012. Experimental study in the Na2O-CaO-MgO-Al2O3-SiO2-CO2 system at $3 \mathrm{GPa}$ : the effect of sodium on mantle melting to carbonate-rich liquids and implications for the petrogenesis of silicocarbonatites. Mineralogical Magazine, 76, 285-309. 
Mysen, B.O., 1999. Structure and properties of magmatic liquids: From haplobasalt to haploandesite. Geochimica et Cosmochimica Acta, 63, 95-112.

Novella, D., Keshav, S., Gudfinnsson, G.H., Ghosh, S., 2014. Melting phase relations of model carbonated peridotite from 2 to $3 \mathrm{GPa}$ in the system $\mathrm{CaO}-\mathrm{MgO}-\mathrm{Al}_{2} \mathrm{O}_{3}-\mathrm{SiO}_{2}-$ $\mathrm{CO}_{2}$ and further indication of possible unmixing between carbonatite and silicate liquids. Journal of Geophysical Research: Solid Earth, 119, 2780-2800.

Olafsson, M., Eggler, D.H., 1983. Phase relations of amphibole, amphibole-carbonate, and phlogopite-carbonate peridotite: petrologic constraints on the asthenosphere, Earth and Planetary Science Letters, 64, 305-315.

Presnall, D.C., Gudfinnsson, G.H., 2005. Carbonate-rich melts in the oceanic low-velocity zone and deep mantle. Geological Society of America, Special Papers 388, 207-216.

Richet, P., Bottinga, Y., 1985. Heat capacity of aluminum-free liquid silicates. Geochimica et Cosmochimica Acta, 49, 471-486.

Russell, J.K., Porritt, L.A., Lavallée, Y., Dingwell, D.B., 2012. Kimberlite ascent by assimilation-fuelled buoyancy. Nature, 481, 352-356.

Rohrbach, A., Schmidt, M.W., 2011. Redox freezing and melting in the Earth's deep mantle resulting from carbon-iron redox coupling. Nature, 472, 209-212.

Ryabchikov, I.D., Brey, G.P., Kogarko, L.N. and Bulatov, V.K., 1989. Partial melting of carbonated peridotite at 50 kbar. (in Russian) Geochimia, No. 1, 3-9.

Sack, R., Ghiorso, M., 1989. Importance of considerations of mixing properties in establishing an internally consistent thermodynamic database: thermochemistry of minerals in the system $\mathrm{Mg}_{2} \mathrm{SiO}_{4}-\mathrm{Fe}_{2} \mathrm{SiO}_{4}-\mathrm{SiO}_{2}$. Contributions to Mineralogy and Petrology, 102, 41-68.

Schmerr, N., 2012. The Gutenberg Discontinuity: Melt at the Lithosphere-Asthenosphere Boundary. Science, 335, 1480-1483.

Sifré, D., Gardés, E., Massuyeau, M., Hashim, L., Hier-Majumder, S., Gaillard, F., 2014. Electrical conductivity during incipient melting in the oceanic low-velocity zone, Nature, 509, 81-85.

Stagno, V., Frost, D.J., 2010. Carbon speciation in the asthenosphere: Experimental measurements of the redox conditions at which carbonate-bearing melts coexist with graphite or diamond in peridotite assemblages. Earth and Planetary Science Letters, $300,72-84$.

Stagno, V., Ojwang, D.O., McCammon, C.A., Frost, D.J., 2013. The oxidation state of the mantle and the extraction of carbon from Earth's interior. Nature, 493, 84-88. 
Schwab, B.E., Johnston, A.D., 2001. Melting Systematics of Modally Variable, Compositionally Intermediate Peridotites and the Effects of Mineral Fertility. Journal of Petrology, 42, 1789-1811.

Takahashi, E., 1986. Melting of a Dry Peridotite KLB-1 up to 14 GPa: Implications on the Origin of Peridotitic Upper Mantle. Journal of Geophysical Research, 91, 9367-9382.

Taylor, W.R., Green, D.H., 1988. Measurement of reduced peridotite-C-O-H solidus and implications for redox melting of the mantle. Nature, 332, 349-352.

Tenner, T.J., Hirschmann, M.M., Withers, A.C., Hervig, R.L., 2009. Hydrogen partitioning between nominally anhydrous upper mantle minerals and melt between 3 and $5 \mathrm{GPa}$ and applications to hydrous peridotite partial melting. Chemical Geology, 262, 42-56.

Tenner, T.J., Hirschmann, M.M., Humayun, M., 2012. The effect of $\mathrm{H}_{2} \mathrm{O}$ on partial melting of garnet peridotite at $3.5 \mathrm{GPa}$. Geochemistry Geophysics Geosystems, 13, doi: 10.1029/2011GC003942.

Thibault, Y., Edgar, A.D., Lloyd, F.E., 1992. Experimental investigation of melts from a carbonated phlogopite lherzolite: Implications for metasomatism in the continental lithospheric mantle. American Mineralogist, 77, 784-794.

Tsuno, K., Dasgupta, R., 2011. Melting phase relation of nominally anhydrous, carbonated pelitic-eclogite at 2.5-3.0 GPa and deep cycling of sedimentary carbon. Contributions to Mineralogy and Petrology, 161, 743-763.

Tumiati, S., Fumagalli, P., Tiraboschi, C., Poli, S., 2013. An Experimental Study on COHbearing Peridotite up to 3.2GPa and Implications for Crust-Mantle Recycling. Journal of Petrology, 54, 453-479.

Ulmer, P., Stalder, R., 2001. The $\mathrm{Mg}(\mathrm{Fe}) \mathrm{SiO}_{3}$ orthoenstatite-clinoenstatite transitions at high pressures and temperatures determined by Raman-spectroscopy on quenched samples. American Mineralogist, 86, 1267-1274.

Wasylenki, L.E., Baker, M.B., Kent, A.J.R., Stolper, E.M., 2003. Near-solidus Melting of the Shallow Upper Mantle: Partial Melting Experiments on Depleted Peridotite. Journal of Petrology, 44, 1163-1191.

Wallace, M.E., Green, D.H., 1988. An experimental determination of primary carbonatite magma composition. Nature, 335, 343-346.

Wyllie, P. J., and W. L. Huang, 1976. Carbonation and melting reactions in the system CaO$\mathrm{MgO}-\mathrm{SiO}_{2}-\mathrm{CO}_{2}$ at mantle pressures with geophysical and petrological applications, Contributions to Mineralogy and Petrology, 54, 79-107. 


\section{Figure 1}

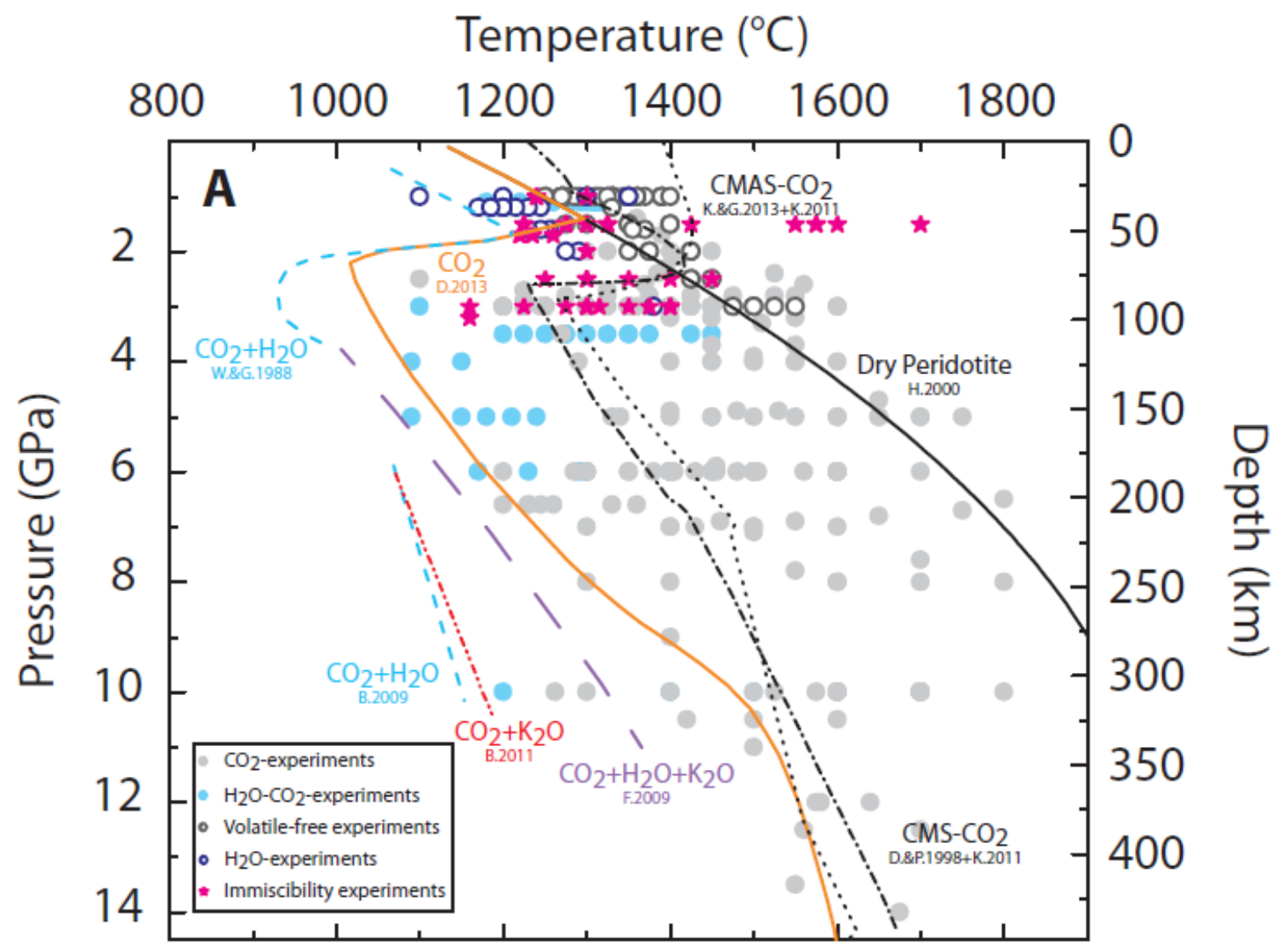


Transition Carbonate-silicate mantle melt model Massuyeau et al. 2015

\section{Figure 2}
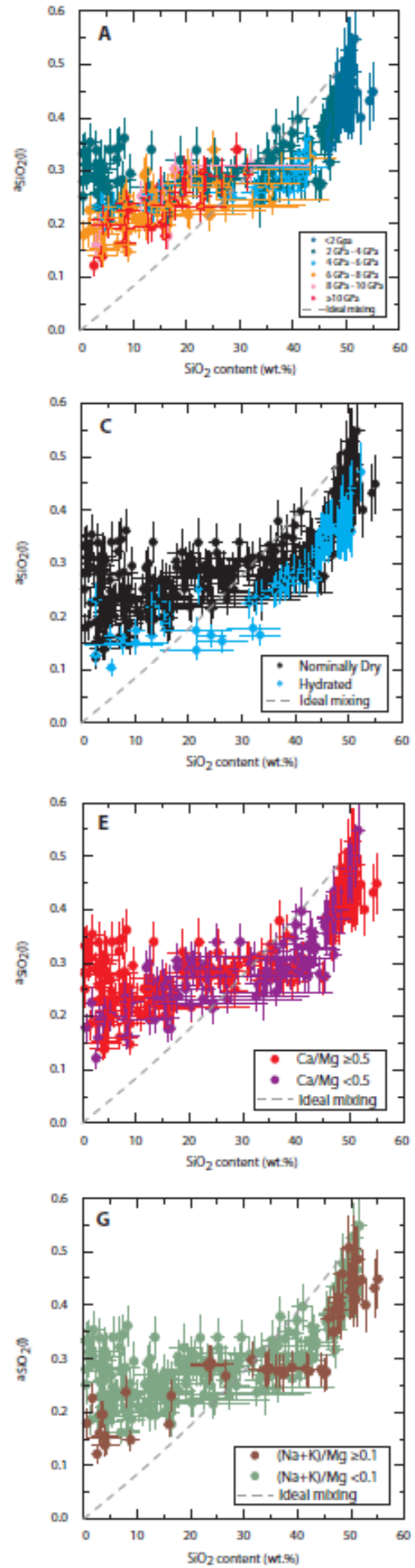
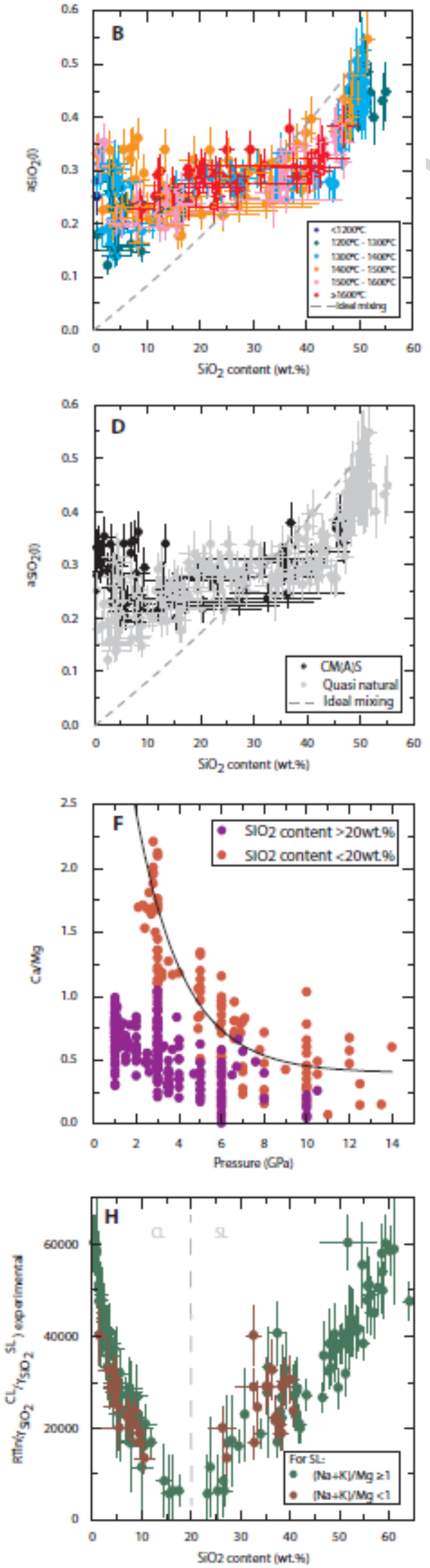
Transition Carbonate-silicate mantle melt model Massuyeau et al. 2015

\section{Figure 3}
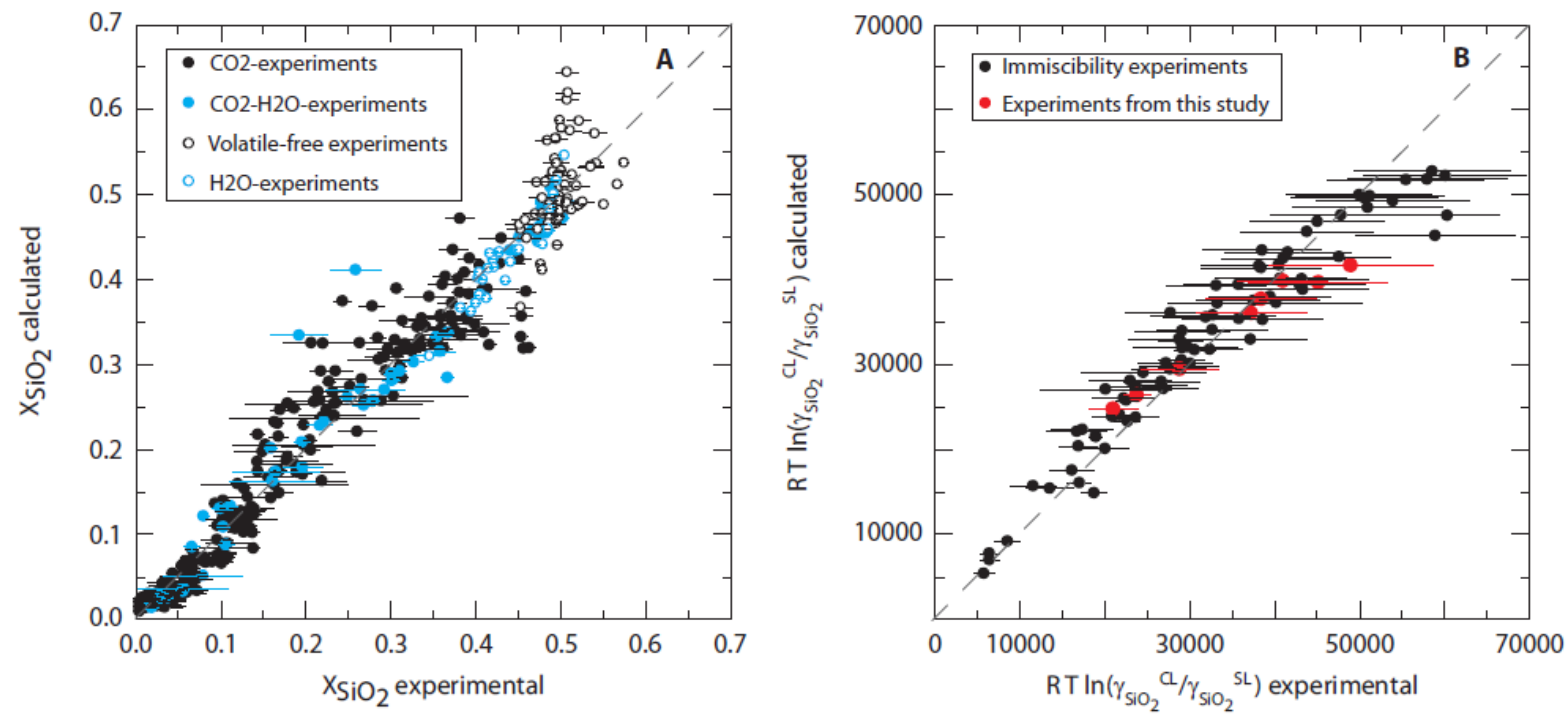


\section{Figure 4}
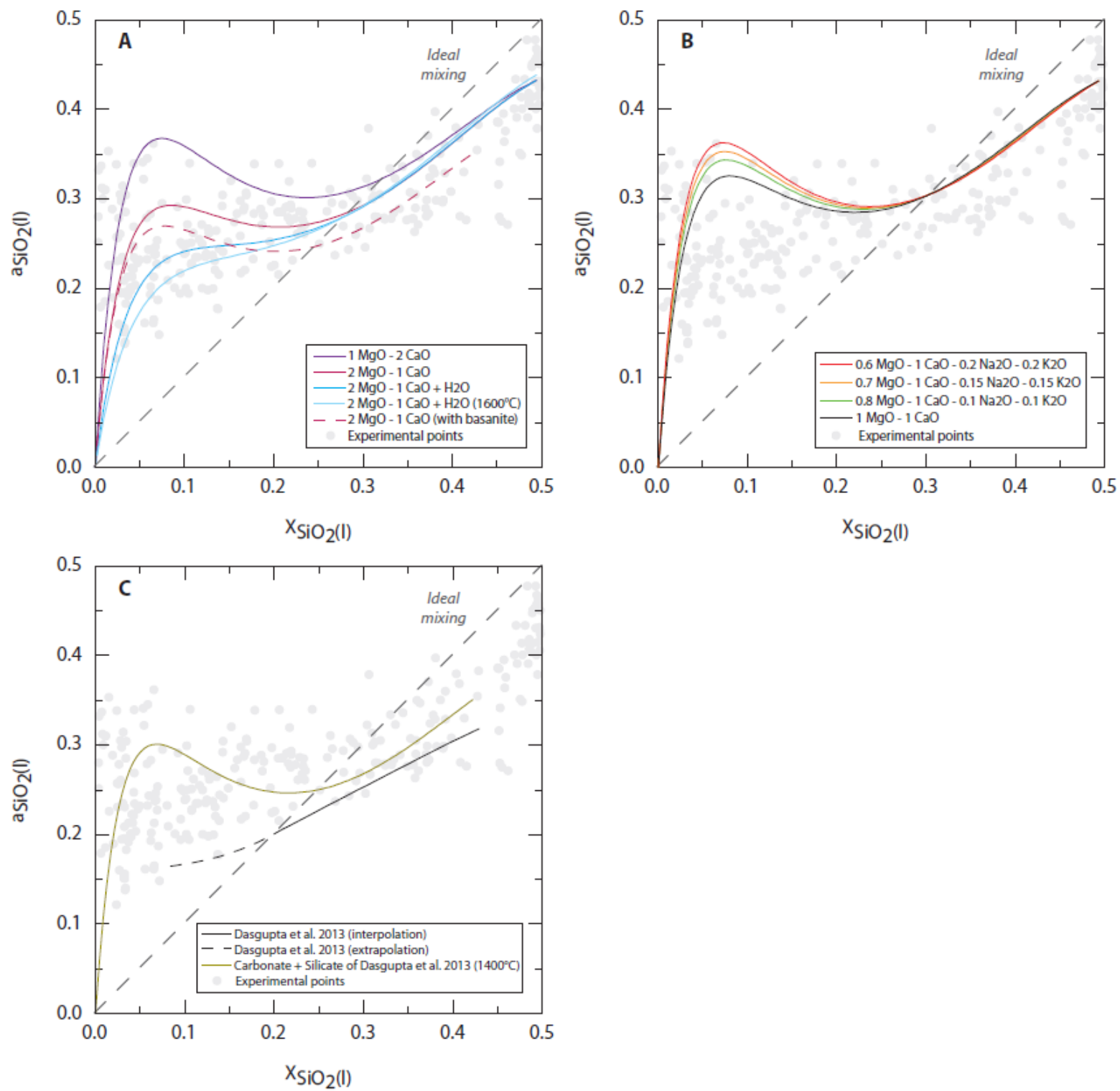
Transition Carbonate-silicate mantle melt model Massuyeau et al. 2015
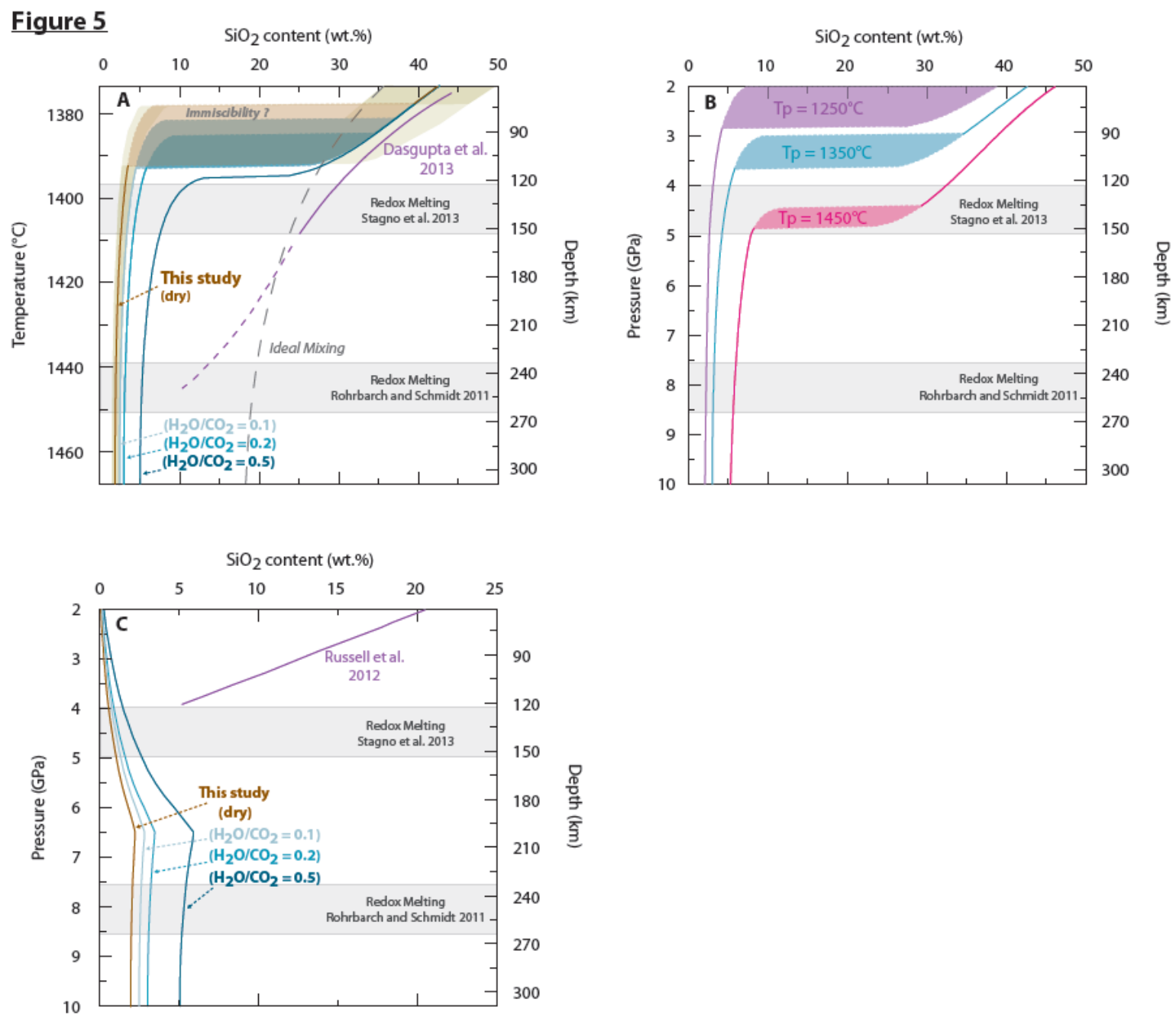


\section{Highlights}

- We use the thermodynamic modelling of the silica activity in melts in $\mathrm{CO}_{2}$-bearing peridotite.

- We define thermodynamic mixing properties between molten carbonate (carbonatite) and molten silicate (basalt).

- A generalized Margules function is adjusted, principally describing the non-ideal interaction for $\mathrm{SiO}_{2}-\mathrm{CO}_{2}$.

- We can characterize the change of the melt composition along ridge adiabatic pressuretemperature paths.

- Carbonatitic liquids stabilized at the onset of incipient melting by "redox melting" $(\sim 150$ $\mathrm{km})$. 